\title{
Subspecies Variation of Daucus carota Coastal ("Gummifer") Morphotypes (Apiaceae) Using Genotyping-by-Sequencing
}

\section{Fernando Martínez-Flores, ${ }^{1,8}$ Manuel B. Crespo, ${ }^{1}$ Philipp W. Simon, ${ }^{2}$ Holly Ruess, ${ }^{2,3}$ Kathleen Reitsma, Emmanuel Geoffriau, ${ }^{5}$ Charlotte Allender, ${ }^{6}$ Najla Mezghani, ${ }^{7}$ and David M. Spooner ${ }^{2}$}

\author{
${ }^{1}$ Departamento de Ciencias Ambientales y Recursos Naturales (dCARN), Universidad de Alicante, Alicante, Spain \\ ${ }^{2}$ Department of Agriculture, Agricultural Research Service, Vegetable Crops Research Unit; and Department of Horticulture, \\ University of Wisconsin, 1575 Linden Drive, Madison, Wisconsin 53706-1590, USA \\ ${ }^{3}$ Bioinformatics Core Facility, Department of Bioinformatics, University of Texas Southwestern Medical Center, Dallas, Texas, \\ USA (current address) \\ ${ }^{4}$ North Central Regional Plant Introduction Station, Iowa State University, Ames, Iowa 50011-1170, USA \\ ${ }^{5}$ IRHS, Agrocampus Ouest - INRA, Université d'Angers, Angers, France \\ ${ }^{6}$ School of Life Sciences, Wellesbourne Campus, The University of Warwick, Wellesbourne, Warwick, England, UK \\ ${ }^{7}$ Banque Nationale de Gènes, Boulevard du Leader Yasser Arafat, Z. I Charguia 1, 1080 Tunis, Tunisia \\ ${ }^{8}$ Author for correspondence (f.mart.flores@gmail.com)

\section{Communicating Editor: Jocelyn Hall}

\begin{abstract}
The genus Daucus is widely distributed worldwide, but with a concentration of diversity in the Mediterranean Region. The D. carota complex presents the greatest taxonomic problems in the genus. We focus on a distinctive phenotypic group of coastal morphotypes of $D$. carota, strictly confined to the margins to within about $0.5 \mathrm{~km}$ of the Mediterranean Sea and the Atlantic Ocean, which we here refer to as coastal morphotypes or D. carota subsp. "gummifer" complex. They are loosely morphologically coherent, sharing a relatively short stature, thick, broad, sometimes highly glossy leaf segments, and usually flat or convex fruiting umbels. We analyzed 288 accessions obtained from genebanks in England, France, and the USA, and an expedition to Spain in 2016, covering the Mediterranean and Atlantic coasts and Balearic Islands, where much of the gummifer complex variation occurs. Our study includes 112 accessions not examined before in this context. Genotyping-by-sequencing identified 29,041 filtered SNPs. Based on high bootstrap support from maximum likelihood and Structure analysis we highlight three main clades. The gummifer morphotypes are intercalated with members of Daucus carota subspecies carota and subspecies maximus in two of these main clades, including a clade containing accessions from Tunisia (also including D. carota subsp. capillifolius) and a clade containing accessions from western Europe (including the British Isles), southern Europe (including the Balearic Islands and the Iberian Peninsula) and Morocco. These results support five independent selections of the gummifer morphotypes in these restricted maritime environments in the Mediterranean and nearby Atlantic coasts. Daucus annuus (=Tornabenea annua) and Daucus tenuissimus (=Tornabenea tenuissima) also fall firmly within D. carota, supporting their classification as morphologically well-defined subspecies of $D$. carota, which are accepted here under the new combinations Daucus carota subsp. annuus and D. carota subsp. tenuissimus, respectively. Types are indicated for most of treated names, including designation of four lectotypes and three epitypes, which fix their further use.
\end{abstract}

Keywords-Daucus carota subspecies maximus, Daucus gingidium, nomenclature, taxonomy, Tornabenea annua, Tornabenea tenuissima.

The genus Daucus L. (Apiaceae) is by any measure taxonomically complex. A morph-anatomical study of Daucus by Sáenz Laín (1981) recognized 20 species. Rubatzky et al. (1999) later estimated 25 species. The phylogenetic relationships among the species of genus Daucus and close relatives in the Apioideae have been clarified by a series of molecular studies using DNA sequences of various plastid genes and plastid introns, plastid DNA restriction sites, nuclear ribosomal DNA internal transcribed spacer (ITS) sequences (reviewed in Spooner 2019); with the ITS region traditionally the most widely used and phylogenetically useful marker used at the genus level (e.g. Spalik and Downie 2007). A study by Banasiak et al. (2016), using DNA sequences from nuclear ribosomal ITS and three plastid markers, is the latest of a series of studies to investigate ingroup and outgroup relationships of Daucus. With data from prior studies, Banasiak et al. (2016) redefined and expanded the genus Daucus to include species from nine other genera now to include about 40 species. This expanded Daucus includes the following genera and species into synonymy: Agrocharis Hochst. (four species), Melanoselinum Hoffm. (one species), Monizia Lowe (one species), Pachyctenium Maire \& Pamp. (one species), Pseudorlaya (Murb.) Murb. (two species), Rouya Coincy (one species), Tornabenea Parl. (six species), Athamanta della-cellae E.A.Durand \& Barratte, and Cryptotaenia elegans Webb ex Bolle (these latter two genera with only this one species transferred to Daucus).
These studies, and additional studies using multiple nuclear orthologs (Arbizu et al. 2014), and DNA sequences from the entire plastid genome (Spooner et al. 2017) are concordant in placing all of the Daucus (s. 1.) taxa with $2 n=18$ chromosomes, including all subspecies of $D$. carota $\mathrm{L}$. and sister species D. sahariensis Murb. and D. syrticus Murb. (e.g. McCollum 1975, 1977; Hauser and Bjørn 2001; Rong et al. 2010) into a welldefined clade, with $D$. syrticus sister to $D$. carota, but for there to be poor resolution among subspecies of $D$. carota within this clade. Diploid chromosome numbers in Daucus range from $2 n=$ 16 to 22, and a tetraploid (D. glochidiatus Fisch. \& C.A.Mey. \& Avé-Lall., $2 n=44)$ and a hexaploid (D. montanus Humb. \& Bonpl. ex Schult., $2 n=66$ ) species have been reported.

As reviewed in Spooner (2019), D. carota has been the subject of many studies based on numerical phenetics and DNA marker-based assessments of diversity and taxonomy. The great morphological variation in $D$. carota has resulted in more than 60 infraspecific taxa, making $D$. carota the most problematic species group in the Apiaceae (Thellung 1926; Heywood 1968a, 1968b; Small 1978; Sáenz Laín 1981; Reduron and Muckensturm 2007; Okeke 2015). There are only weak, if any, biological barriers to intercrossing of these many infraspecific taxa. Iorizzo et al. (2013) conducted a notable study of genetic structure and domestication of carrot using 3326 single nucleotide polymorphisms (SNPs) and found a clear separation between wild accessions of D. carota (subsp. carota) and cultivated ones (subsp. sativus (Hoffm.) Schübl. \& G.Martens), 
with subsp. sativus supported to have an origin in central Asia. Relative to the present study, Spooner et al. (2014) studied the practical subspecies variation within $D$. carota, with 36 morphological characters of genebank accessions planted in a common garden. Multivariate analyses of these data were able to identify only three wild subspecies (subsp. capillifolius (Gilli) Arbizu, subsp. carota, and subsp. gummifer (Syme) Hook.f.), but even these showed great overlap of "taxon-specific" characters. There is no consensus and the number of infraspecific taxa in Daucus carota is evident when various publications are compared. For example, Sáenz Laín (1981) recognizes five taxa, Heywood (1968a) 12 taxa, Okeke (2015) 14 taxa, and Reduron and Muckensturm (2007) 17 taxa. Prior molecular studies failed to distinguish any of these subspecies. Taxonomists have attempted to assign names to many of them but there has been little consistency in their use.

Despite the great variation of many apparently intergrading subspecies within D. carota, there are two somewhat welldefined phenotypic groups: 1) plants with a relatively short stature, thick, broad leaf segments, and usually flat or convex fruiting umbels, distributed in the coastal regions of the Mediterranean basin (mostly in the western and central areas) and Atlantic coasts of northern Africa, Portugal, Spain, France, and the UK (D. carota subsp. gummifer); and 2) the remaining subspecies possessing taller plants with thinner narrower leaf segments and fruiting umbels that are frequently curved upward and that close into a characteristic concave "bird's nest" form, co-occurring with the gummifer morphotypes in coastal regions but, unlike the gummifer morphotypes, extending into inland regions and over a greater distributional range that includes Asia, Australia, and the Americas (considered invasive weeds in many areas). Onno (1937) classified populations of the first group as D. gingidium L., containing eight subspecies, and the latter as D. carota, including four subspecies. Small (1978) and Reduron and Muckensturm (2007) recognized two "species aggregates," or "subgroups," within the single species D. carota corresponding to the above two groups. Reduron and Muckensturm (2007) recognized five subspecies within subgroup carota and four subspecies within subgroup gummifer. Heywood (1968b), Sáenz Laín (1981), and Pujadas-Salvà (2003) recognized only a single species, but without the division into subgroups, and each author differed in the number of their recognized subspecies.

While it is easy to distinguish the coastal ("gummifer") morphotypes as a group morphologically distinct from inland ("carota") morphotypes, it is problematic to recognize taxa within these two groups. Relative to the present study, Arbizu et al. (2016) used genotyping-by-sequencing (GBS) to investigate the subspecies variation of $D$. carota. Consistent with prior results, the data separated species with $2 n=18$ chromosome from all other species and placed all cultivated carrots (D. carota subsp. sativus) in a single clade. Most notably, it supported clear geographic segregates of the wild members of D. carota, with the gummifer morphotypes divided among these segregates with which they co-occur. That is, they were not a monophyletic group at all, but resulted from parallel selection of a suite of characters adapted to coastal environments. Mezghani et al. (2018) extended these studies with new collections from Tunisia and showed yet another geographical region from which the gummifer type evolved. Taxonomists have tried to assign names to the gummifer morphotypes but they are so polymorphic that identification is difficult and there has been no consistent application of their names.
Subsequent to these studies, we assembled a much broader collection of gummifer morphotypes from expeditions to Spain in 2016, and from genebanks in England and France that provided us with sufficient germplasm to address a comprehensive taxonomy of the gummifer types. The purpose of our study is to examine these new collections, with the prior results, with GBS and Structure analysis to provide insights on the subspecies variation of the gummifer morphotypes of D. carota.

\section{MAterials AND Methods}

Plant Material-Supplementary Table 1 (Martínez-Flores et al. 2020) lists the 288 accessions, including 112 accessions of critical germplasm from areas not examined before (the 112 newly examined accessions are highlighted in red on Fig. 1), obtained from genebanks in England (the UK Vegetable Genebank), France (IRHS, Agrocampus Ouest-INRA, Universite $\mathrm{d}^{\prime}$ Angers), and the United States (National Plant Germplasm System, maintained at the North Central Regional Plant Introduction Station - NCRPIS) and from the 2016 expedition in Spain, including the Mediterranean and Atlantic coasts and Balearic Islands, where much of the gummifer complex variation occurs. Two of these accessions (NGBTUN 86, D. carota subsp. capillifolius, and NGBTUN 166, D. carota subsp. carota) were examined in separate GBS reactions, resulting in 289 terminals on our tree. The additional 175 accessions were studied in the GBS studies of Arbizu et al. (2016) using D. carota diversity then available to us, and Mezghani et al. (2018) who focused on accessions from Tunisia (accessions from both of these studies are highlighted in green on Fig. 1). Figure 2 maps all of the accessions used in our study possessing sufficient locality data, and divides them into cultivated accessions (D. carota subsp. sativus) and wild accessions (all of the other subspecies of D. carota, and Daucus annuus ( $\equiv$ Tornabenea annua) and Daucus tenuissimus ( $\equiv$ Tornabenea tenuissima), both from Cape Verde Island. Figure 3 provides distributional detail of all of the wild accessions possessing sufficient locality data from the western Mediterranean Region and southern England and adjacent northern France, where all of the gummifer morphotype accessions occur.

Our initial identifications of our examined accessions were based on germplasm collection expeditions in Tunisia (two trips, 2007, 2009), Morocco (two trips 2012, 2013) and Spain (three separate trips to capitalize on different species phenology in 2016), grow outs at the USDA carrot genebank in Ames, Iowa of genebank accessions from these collections and from the England and French genebanks, and on the morphometric study of Daucus carota (Spooner et al. 2014; Martínez-Flores 2016; Mezghani et al. 2017). Based on these cumulative data we initially identified our specimens to five widely intergrading subspecies that are frequently accepted in regional floras and monographs on the genus Daucus. Basic identification criteria (often subjective) were used as follows:

1. Daucus carota subsp. capillifolius: Pale yellow petals; very narrow sublinear "leaflets" lobes; sub-erect branches; fruiting umbel with markedly concave shape ("close nest-like"); flowering umbel shape slightly convex to flat; bracts with narrow sublinear segments; number of umbel rays generally $18-25$; mericarp length $4.5-5.5 \mathrm{~mm}$; root not fleshy.

2. Daucus carota subsp. gummifer (s. 1.): White to pinkish petals; fleshy and wide "leaflets" with broad lobes; spreading-ascending branches; fruiting umbel with convex to concave ("open nest-like") shape; flowering umbel shape hemi-spherical to convex; bracts with broad, occasionally sublinear, segments; primary umbel diameter and number of rays highly variable; mericarp length less than $4.5 \mathrm{~mm}$; root not fleshy.

3. Daucus carota subsp. carota (common wild carrot growing worldwide): White to pinkish petals; "leaflets" with narrow lobes, not fleshy; sub-erect branches; fruiting umbel with markedly concave shape ("close nest-like"); flowering umbel shape slightly convex to flat; bracts with narrow sublinear segments; primary umbel with $<15 \mathrm{~cm}$ diameter and $<70$ rays; mericarp length less than $4.5 \mathrm{~mm}$; root not fleshy.

4. Daucus carota subsp. maximus (Desf.) Ball: White to pinkish petals; "leaflets" with narrow lobes, not fleshy; sub-erect branches; fruiting umbel with markedly concave shape ("close nest-like"); flowering umbel shape slightly convex to flat; bracts with narrow sublinear segments; primary umbel with $>15 \mathrm{~cm}$ diameter and $>80$ rays; mericarp length less than $4.5 \mathrm{~mm}$; root not fleshy. Because of widespread intergradation, it is particularly very difficult to distinguish subsp. maximus from subsp. carota.

5. Daucus carota subsp. sativus (Hoffm.) Arcang. (cultivated carrot): White to pinkish petals; "leaflets" with narrow lobes, not fleshy; sub-erect branches; fruiting umbel with flat to concave ("open nest-like") shape; 


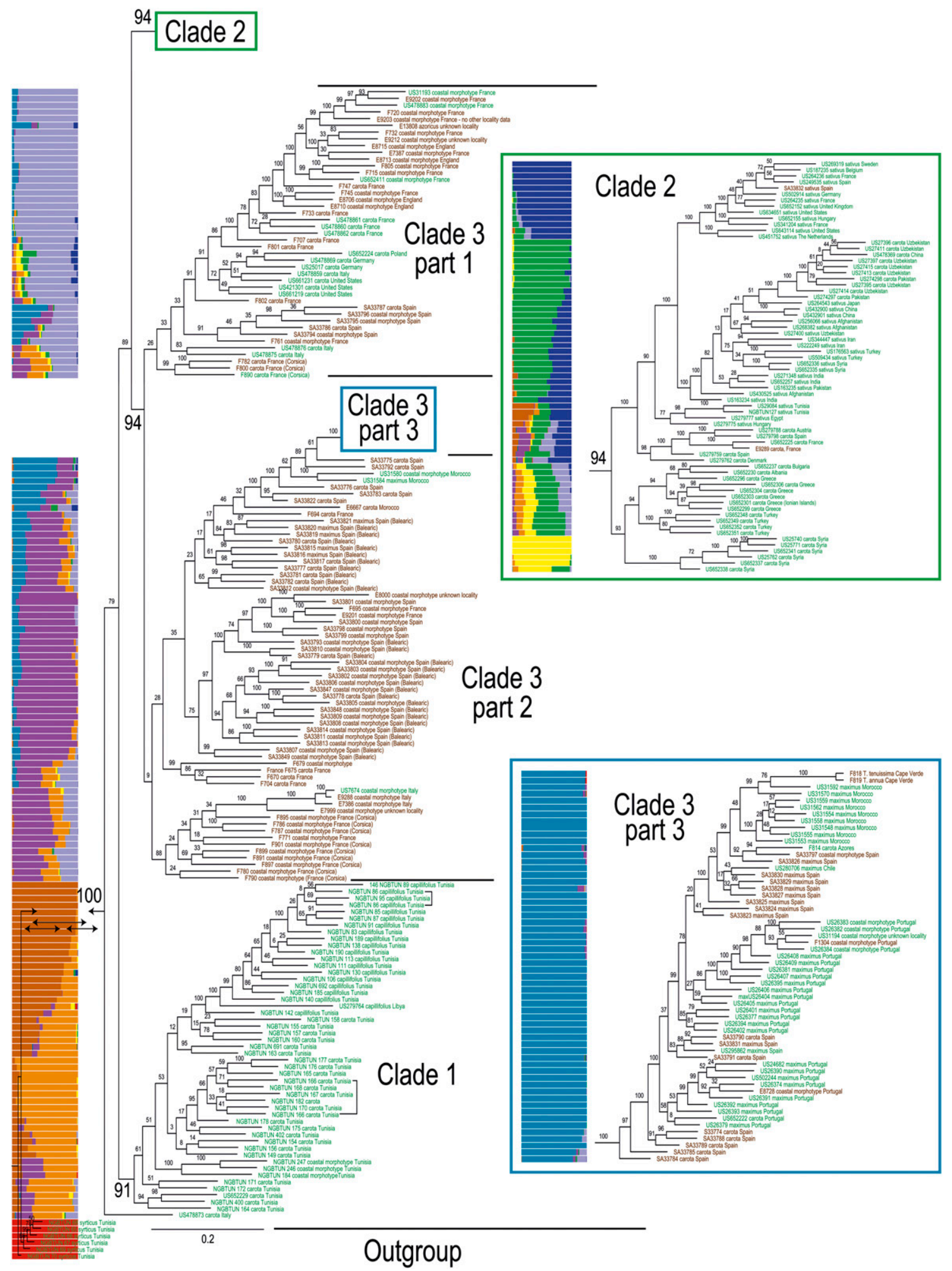

FIG. 1. Maximum likelihood reconstruction and structure of the genetic diversity of 288 accessions of the Daucus carota complex and outgroup, using 29,041 SNPs obtained by genotyping-by-sequencing. Each accession is represented by a horizontal bar, and each color corresponds to a theoretical population (nine in total). Numbers above the branches represent bootstrap values. Daucus syrticus is the outgroup. Accessions previously studied in Arbizu et al. (2016) and Mezghani et al. (2018) are marked in green.

flowering umbel shape slightly convex to flat; bracts with narrow sublinear segments; primary umbel with $<15 \mathrm{~cm}$ diameter and $<70$ rays; mericarp length less than $4.5 \mathrm{~mm}$; root swollen, fleshy.

Genotyping-by-Sequencing, Phylogenetic Analysis-The entire pipeline from the construction and sequencing of GBS libraries, and GBS analysis, and phylogenetic analysis of the GBS data follows Mezghani et al.
(2018). Samples were processed with the TASSEL v. 5.2.31 (Bradbury et al. 2007; Glaubitz et al. 2014) pipeline (standard protocol except where noted): 1) GBSSeqToTagDBPlugin-e ApeKI; 2) TagExportToFastqPlugin- c 2; 3) bwa aln ( $\mathrm{Li}$ and Drubin 2009); 4) bwa samse (Li and Drubin 2009); 5) SAMToGBSdbPlugin; 6) DiscoverySNPCallerPluginV2gapAlignRatio 1-sC Chr1-eC Chr9; 7) SNPQualityProfilerPlugin; 8) 


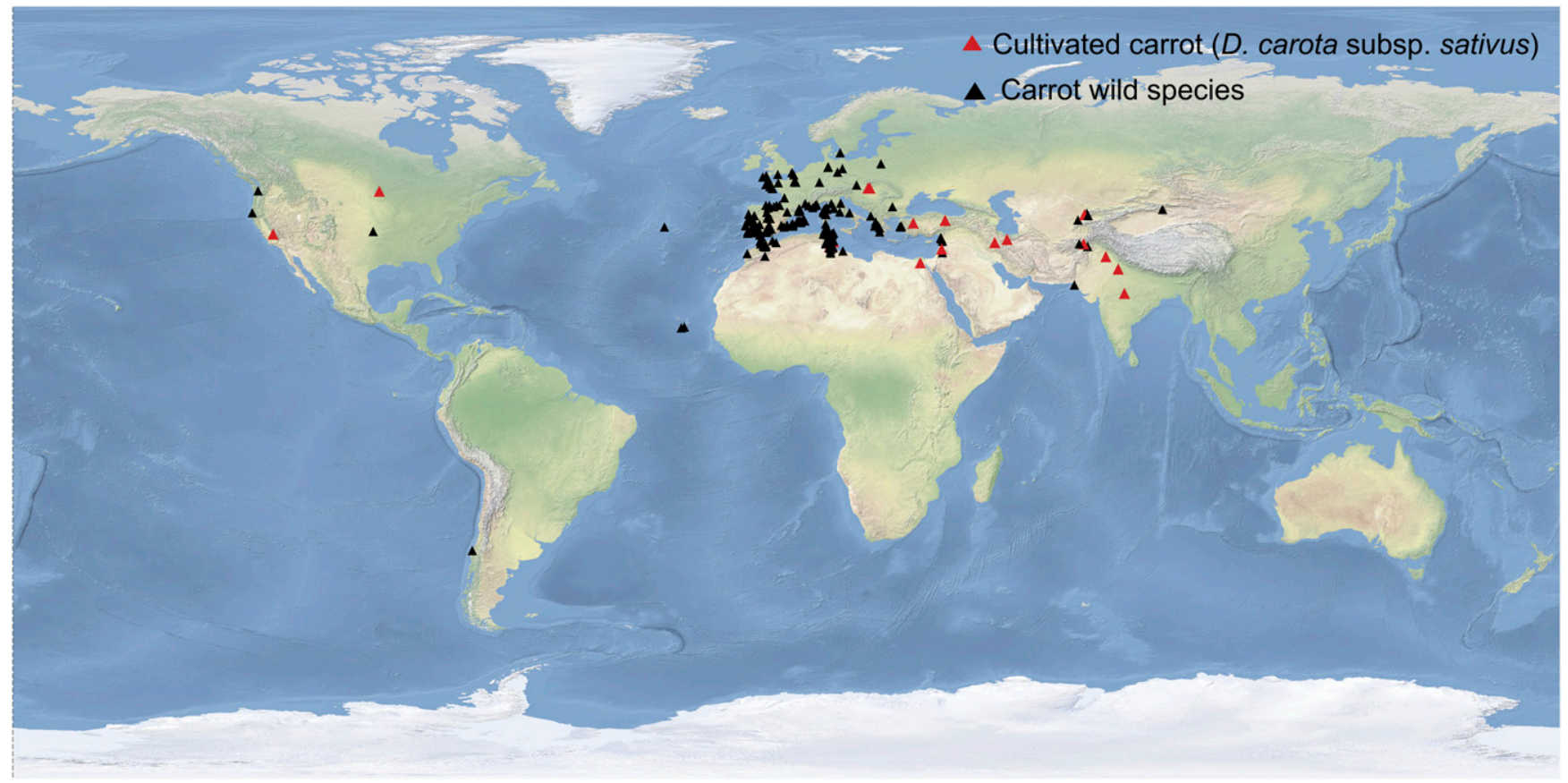

FIG. 2. Distribution of accessions used in our study (possessing sufficient locality data). Red triangles = cultivated accessions (Daucus carota subsp.

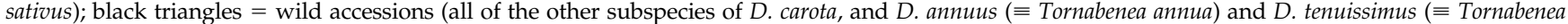
tenuissima)). See Supplementary Table 1 (Martínez-Flores et al. 2020) for a detailed list of accessions.

ProductionSNPCallerPluginV2-e ApeKI. Daucus carota subsp. sativus double-haploid DH1 was used as the reference sequence (Iorizzo et al. 2016). The resulting unfiltered vcf file was filtered with vcftools v. 0.1.14 (Danecek et al. 2011) for the max-alleles of 2, max-missing 0.9, minimal maf of 0.1 , andmax-maf of 0.5. SNPs were further filtered by using the customscriptSNPfilter4ML.pl (https://www.github.com/HollyRuess/ hrbi_perl) in order to run the ascertainment bias correction in RAxML (Stamatakis 2014). SNPs which have an alternate base of "N" were also removed from the file. The vcf file was converted to PHYLIP format by using TASSEL v. 5.2.31 (Bradbury et al. 2007) -exportType Phylip_Inter. Phylogenetic analysis of the GBS data using maximum likelihood (ML) was performed on the filtered data by using raxmlHPC-PTHREADS v. 8.2.3 (Stamatakis 2014), with bootstrap calculated on 100 trees, model of ASC_GTRGAMMA, and the ascertainment correction of Lewis (2001). Trees were viewed in FigTree v. 1.4.0 (http://tree.bio.ed.ac.uk/software/ figtree/). Maximum likelihood is the dominant method for analyzing GBS data. Populations of $D$. carota can readily hybridize experimentally and in nature across traditional subspecies boundaries (Spooner 2019). While this could argue for the use of network analyses, rather than strictly tree-like (ML) analysis we used here, we used ML because this is a worldwide study where local hybridization cannot occur over wide distances, and prior analysis of Arbizu et al. (2016) demonstrated the ability of this technique to identify well-defined geographic clusters.

Structure Analysis-The filtered VCF data set was reordered (by top to bottom ML tree order) and converted to STRUCTURE format using a custom script vcf2STRUCTURE_reorder.pl (github.com/HollyRuess/ hrbi_perl). GNU Parallel (Tange 2011) processed six jobs simultaneously in STRUCTURE, with a 270 sec delay between jobs. Population structure was calculated using STRUCTURE v. 2.3.4 (Pritchard et al. 2000), with population $\mathrm{K}$ values of 1 to 12 , replicated three times, with a burn-in length of 20,000 and 50,000 Monte Carlo iterations. Estimation of the optimal K value was calculated by the Evanno method (Evanno et al. 2005) and population structure plots were generated with POPHELPER v. 2.2.5.1 (Francis 2017).

Supplementary Table 1, Figure 1, maximum likelihood file, and associated VCF file can be accessed via Dryad Digital Repository (MartínezFlores et al. 2020).

\section{RESUlts}

Cladistic and Structure Results-Before filtering, GBS identified 580,610 SNPs; after filtering, 29,041 SNPs. We highlight three well-supported main clades based on high bootstrap values (Table 1; Figs. 1, 4-6). Clade 1 (bootstrap support, BS $=91 \%$, Fig. 4) contains plants from Tunisia and northwestern Libya (Supplementary Table 1, Martínez-Flores et al. 2020), of Daucus carota subsp. capillifolius, D. carota subsp. carota, and three gummifer morphotype accessions on Galite Island, northern Tunisia and the adjacent mainland just to the south. All accessions of subsp. capillifolius in Clade 1 form a $100 \%$ bootstrap support subclade except for a few intermediate accessions as possible subsp. carota $\times$ subsp. capillifolius hybrids (e.g. NGBTUN 155, 157, 158, and 160). Likewise, all three accessions of gummifer morphotype form a clade with $100 \%$ bootstrap support. The two accessions examined in separate GBS reactions (NGBTUN 86, D. carota subsp. capillifolius, and NGBTUN 166, D. carota subsp. carota; designated in brackets in Figs. 1, 6) are very close to each other on the tree. The remaining accessions, $D$. carota subsp. carota, are interspersed between subsp. capillifolius and gummifer morphotypes.

The Structure analysis grouped accessions included in this study into $\mathrm{K}=$ nine populations. They are informally denoted here as red, brown, orange, indigo, green, yellow, cyan, blue, and purple (see colors in Fig. 1). As it is shown in Fig. 1, Daucus syrticus accessions were strongly associated with the red single theoretical population (outgroup). Red membership was almost absent in the remaining accessions (ingroup). The highest brown percentage was found in Daucus carota subsp. capillifolius from Tunisia. Brown membership was very limited outside of the Tunisia and Libya area. Orange group was mostly represented by Daucus carota subsp. carota specimens collected in Tunisia. Outside this territory, orange membership was limited and the highest percentages were found in plants from Corsica, Libya, Italy, southern France, the Balearic Islands, Greece and Turkey. "Western" Daucus carota subsp. satious were largely associated with the indigo group. This membership was also high in several "eastern" subsp. sativus 


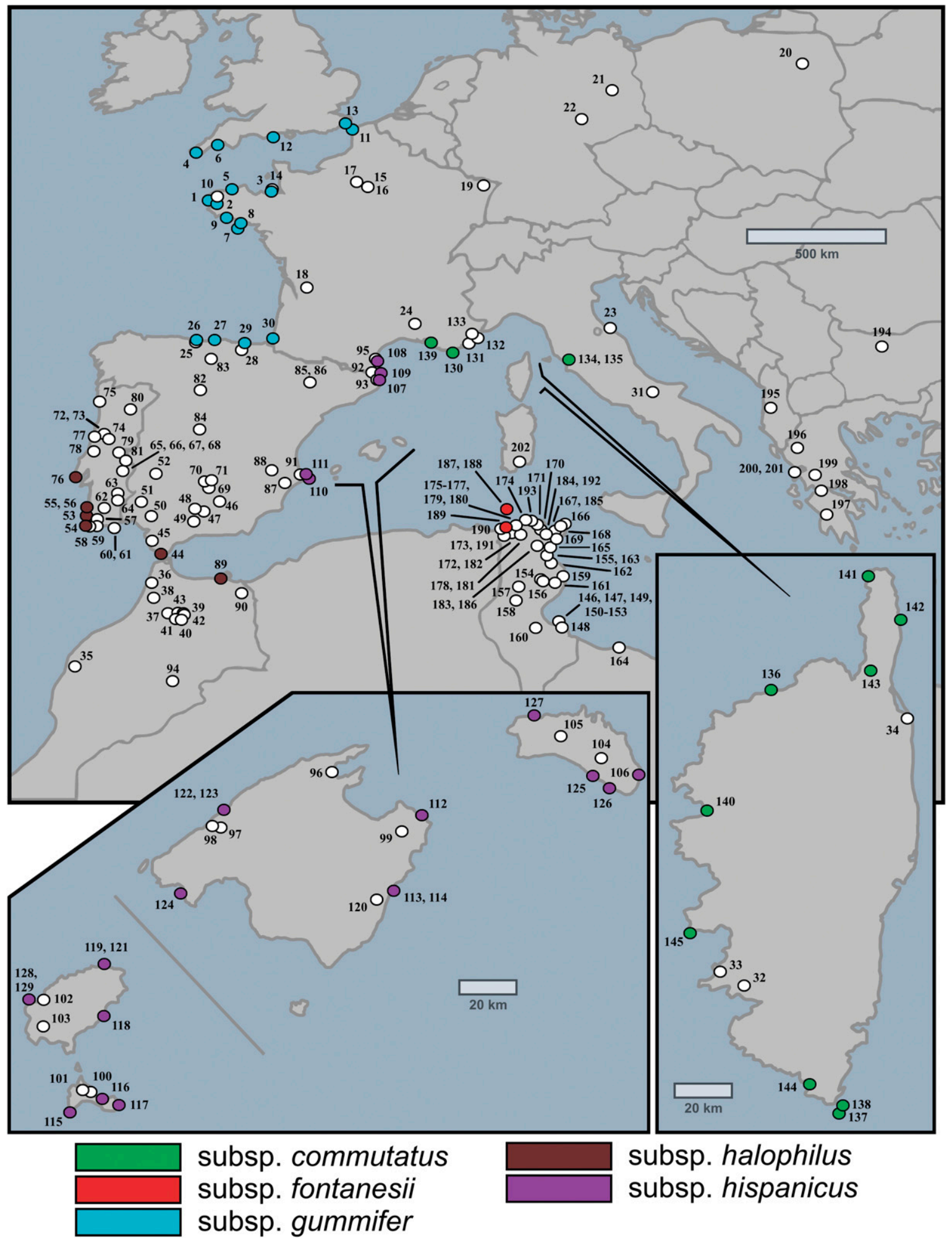

FIG. 3. Distribution of the wild accessions (possessing sufficient locality data) from the western Mediterranean Region as well as southern England and adjacent northern France, where all of the gummifer morphotypes occur. Numbers according to Figs. 4-6. See Supplementary Table 1 (Martínez-Flores et al. 2020) for a detailed list of records and corresponding numbers.

plants and few European subsp. carota specimens within Clade 2. Maximum green percentage was found in subsp. carota accessions from Asia, although this group was also well represented in Asian subsp. sativus and eastern Mediterranean subsp. carota specimens. Yellow group characterized Daucus carota subsp. carota accessions collected in Syria, while limited yellow membership was mainly found in subsp. carota plants from Albania, Bulgaria, Greece, and Turkey. The highest cyan membership was found in gummifer morphotypes from the English Channel coasts and subsp. carota specimens mainly 
TABLE 1. Taxa and countries of occurrence in the three main clades and subclades supported in this study, with associated bootstrap values (BS) in parentheses.

\begin{tabular}{lr}
\hline \hline \multicolumn{1}{c}{ Taxa } & \multicolumn{1}{c}{ Countries } \\
\hline $\begin{array}{l}\text { Clade } 1(91 \%) \text { carota, capillifolius, gummifer } \\
\text { Clade } 2(94 \%)\end{array}$ & Tunisia, Libya \\
carota, sativus & Afghanistan, Albania, Austria, Belgium, Bulgaria, China, Denmark, \\
& Egypt, France, Germany, Greece, Hungary, India, Iran, Japan, Pakistan, \\
& Spain, Sweden, Syria, The Netherlands, Tunisia, UK, USA, Uzbekistan
\end{tabular}

Clade $3(94 \%)$

Clade $3(1)(26 \%)$

carota, gummifer, maximus

Grade 3(2) (9\%)

carota, gummifer, maximus

Clade 3(3) (100\%)

carota, maximus, Tornabenea annua, Tornabenea tenuissima

England, France, France (Corsica), Germany, Italy, Poland, Spain, USA

France, France (Corsica), Italy, Morocco, Spain, Spain (Balearic)

Azores, Cape Verde, Chile, France, Morocco, Portugal, Spain

collected in France. The blue group was strongly associated with many Daucus carota subsp. maximus accessions from western Mediterranean and with several subsp. carota and gummifer morphotype specimens from the same area. Remarkably, same group association was found in samples of the former genus Tornabenea. Gummifer morphotype specimens from the Balearic Sea and western Gulf of Lion areas showed the highest purple group percentages. Moderate purple membership was also found in gummifer morphotype accessions from Corsica and Italy, and several subsp. carota plants from Balearic Islands.

Clade 2 (BS $=94 \%$, Fig. 5) includes all accessions of cultivated carrot (D. carota subsp. sativus) from throughout a worldwide geographic area on a $90 \%$ BS supported clade. The accessions of subsp. sativus are strongly divided into two $100 \%$ bootstrap supported subclades into "western" and "eastern" clades. The eastern subclade contains ten accessions of subsp. carota from the central Asian area of NW China (one accession), Pakistan (two accessions), and Uzbekistan (seven accessions). Clade 2 also contains 24 accessions of Daucus carota subsp. carota outside of this $90 \%$ BS clade from Albania, Bulgaria, Austria, Denmark, France, Greece, Spain, Syria, and Turkey. The five accessions of subsp. carota from Syria are notably distinct with $100 \%$ bootstrap support, also well-defined by Structure analysis (yellow on Fig. 1), sharing alleles with a well-defined clade of subsp. carota from geographically contiguous Turkey, Greece, Albania, and Bulgaria.

Clade 3 (BS $=94 \%$, Figs. 5, 6) contains specimens mainly collected in western Africa, western Europe (including the Mediterranean islands of Corsica and the Balearic Islands), and

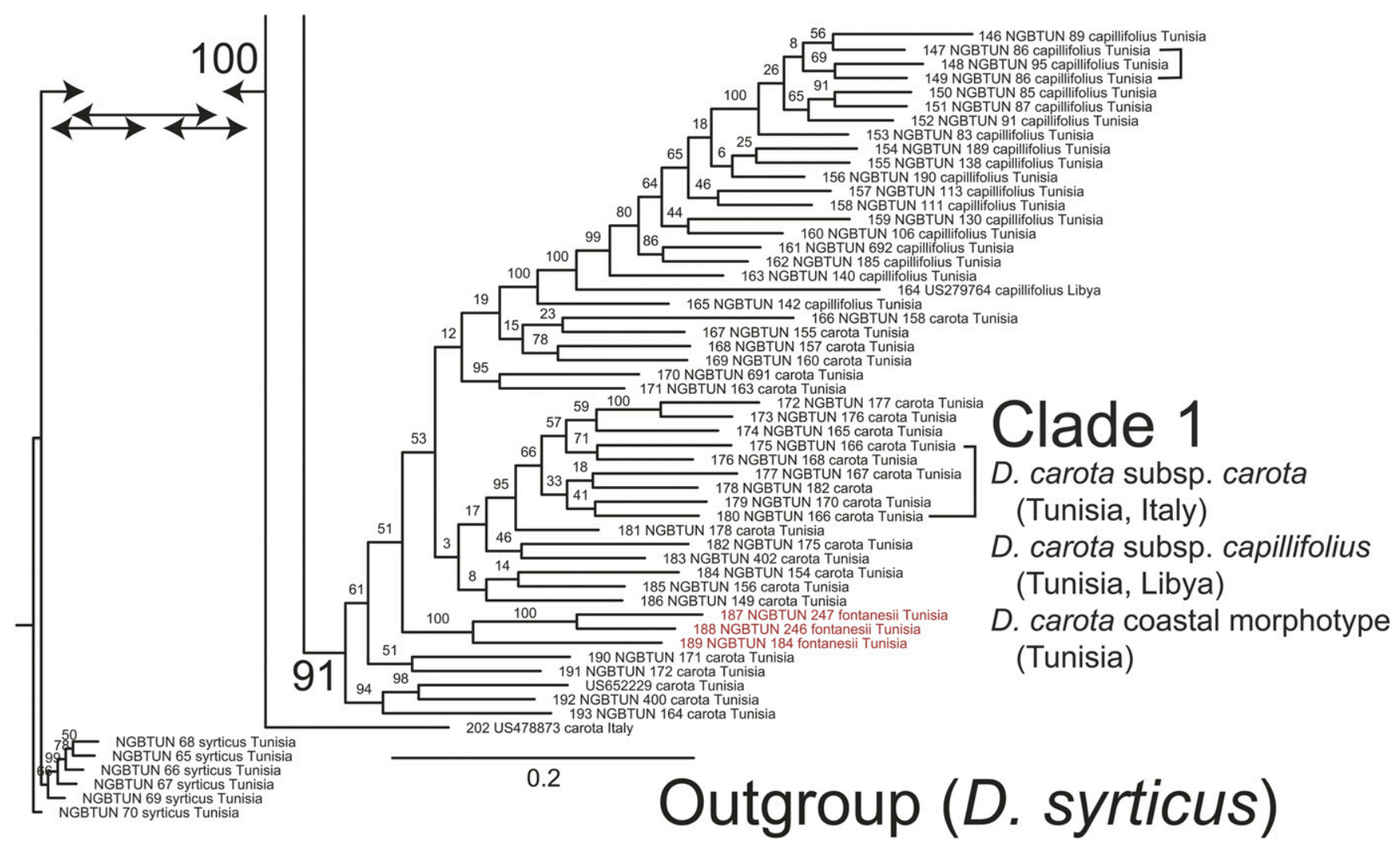

FIG. 4. Detail of Clade 1 and the outgroup from Fig. 1. Names on the clade refer to geographic origin of the samples. Numbers before accession names correspond to Fig. 3 map."Coastal morphotypes" are marked in red. See Supplementary Table 1 (Martínez-Flores et al. 2020) for a detailed list of records and corresponding numbers. 


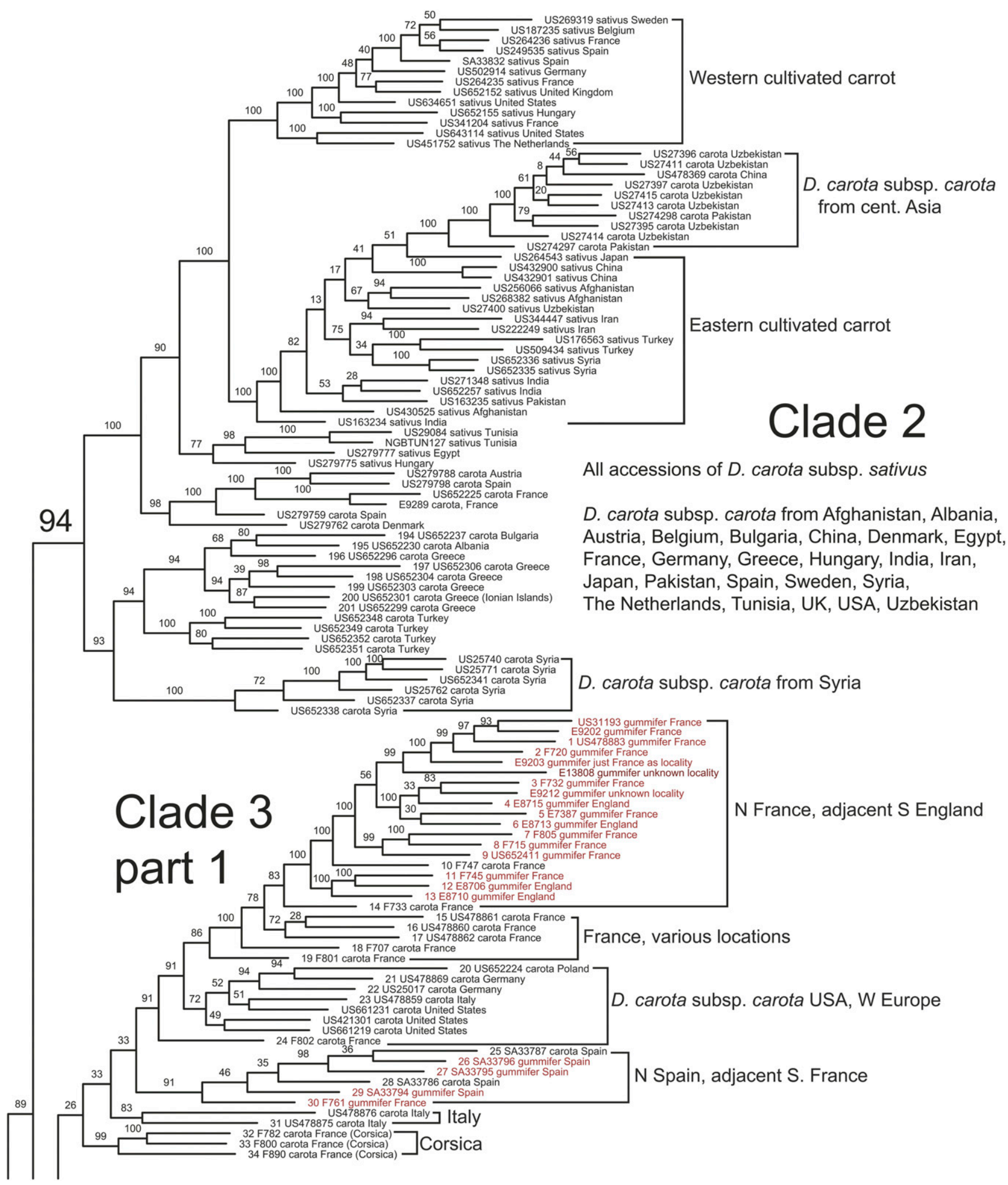

FIG. 5. Detail of Clade 2 and Clade 3 part 1 from Fig. 1. Names on the clades refer to geographic origin of the samples. Numbers before accession names correspond to Fig. 3 map. "Coastal morphotypes" are marked in red. See Supplementary Table 1 (Martínez-Flores et al. 2020) for a detailed list of records and corresponding numbers.

the Atlantic islands of the Azores, and Cape Verde Island, collectively identified as Daucus carota subsp. carota, D. carota subsp. maximus, gummifer morphotypes, and Tornabenea annua and T. tenuissima (the latter two in Cape Verde). Daucus carota subsp. carota, subsp. maximus, and gummifer morphotypes are widely intermixed among subspecies. In summary, regarding D. carota, subsp. capillifolius is confined to Clade 1 and monophyletic, subsp. satious to Clade 2 and is paraphyletic, gummifer morphotypes to Clades 1 and 3 and is polyphyletic, subsp. maximus to Clade 3 and is polyphyletic, and subsp. carota is in all three clades. 


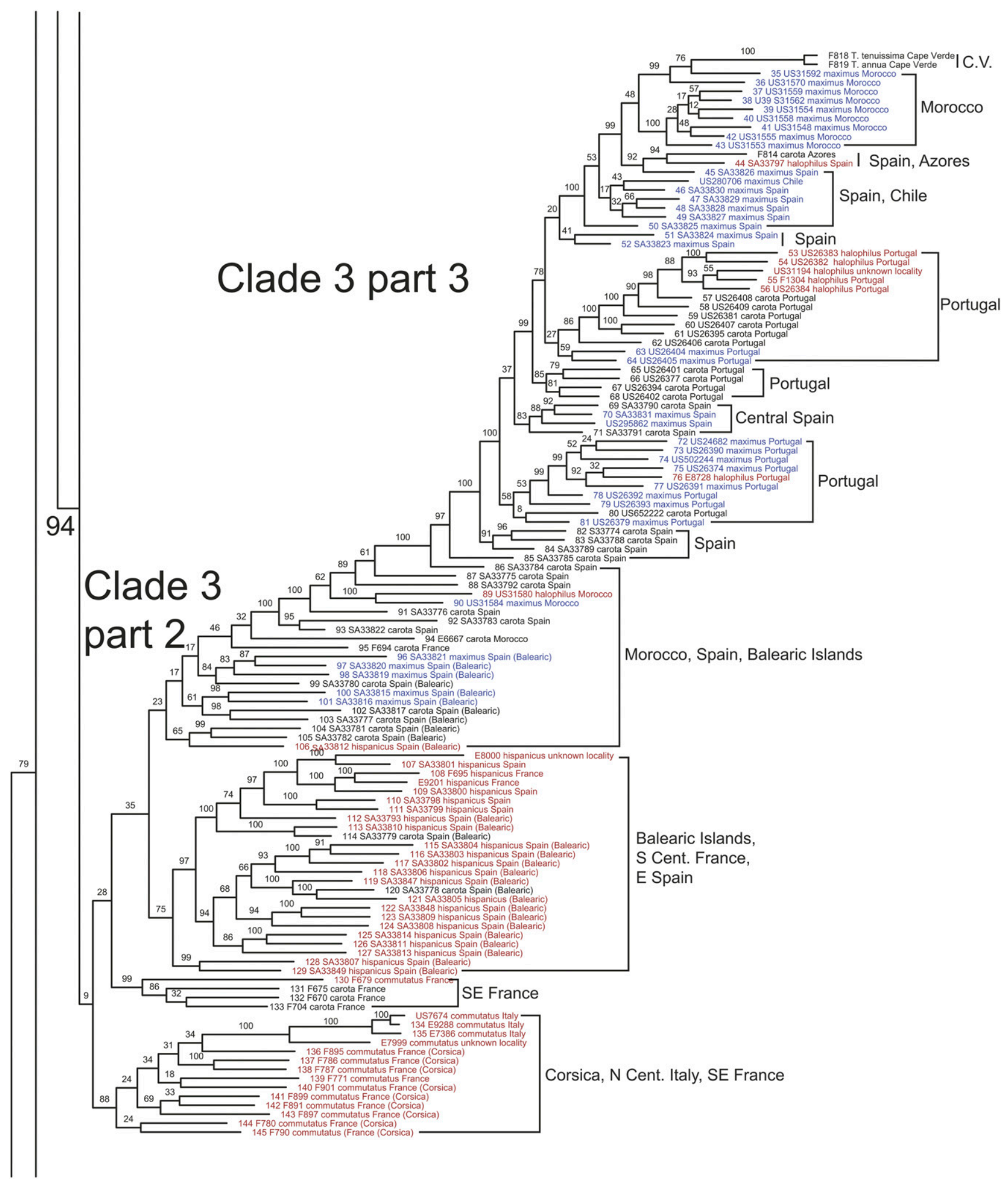

FIG. 6. Detail of Clade 3 parts 2 and 3 from Fig. 1. Names on the clades refer to geographic origin of the samples. Numbers before accession names correspond to Fig. 3 map. Daucus carota subsp. maximus accessions are marked in blue and "coastal morphotypes" in red. See Supplementary Table 1 (Martínez-Flores et al. 2020) for a detailed list of records and corresponding numbers.

Discussion

Systematics of Daucus carota s. l.-Our study demonstrates that although morphology fails to distinguish the traditional subspecies of the gummifer (coastal) morphotypes, GBS data generally separates them into well-defined geographic areas. We here redefine the gummifer complex subspecies based entirely on their location and genetic structure, rather than their morphology, and assign names to these segregants based on names assigned to types described from the areas where they occur. These results support five 
independent selections of the gummifer morphotypes in these narrowly restricted maritime environments in the Mediterranean Region and nearby Atlantic coasts. Daucus annuus (=Tornabenea annua) and Daucus tenuissimus (=Tornabenea tenuissima; Cape Verde) also fall firmly within Daucus carota, supporting their classification as morphologically welldefined subspecies of $D$. carota, which are accepted here with new combinations. Types are indicated for most of the treated names, including designation of four new lectotypes and three new epitypes, which contribute to fixation of further use of these names.

Arbizu et al. (2016) demonstrated the utility of GBS to discriminate population structure within the D. carota complex. Their analyses supported the specimens usually included within the gummifer complex to have separate and independent origins from subsp. carota and subsp. maximus in maritime habitats. Our present study, using additional samples from more diverse geographic origins, provides support to the concept of the Daucus carota complex containing geographically-defined subspecies, but they (except D. carota subsp. capillifolius) lack good morphological support. Further studies should concentrate on identification of new macro- and micromorphological characters facilitating morphological recognition of the subspecies accepted here.

There is a striking relationship between the cladistic results (Figs. 1, 4-6) and these gummifer morphotype geographical distributions (Fig. 3), which we here identify as five subspecies based on the formal subspecies names described from these five areas, with all accessions occurring at or very near $(0.5 \mathrm{~km})$ the Atlantic and Mediterranean coasts. According to our sampling, each subspecies shows a rather well defined distribution: 1) Subspecies gummifer occurs along both coasts of the English Channel and Bay of Biscay area. 2) Subspecies hispanicus (Gouan) Thell. occurs in the Balearic Islands and western Gulf of Lion area. 3) Subspecies halophilus (Brot.) A.Pujadas occurs in southern Portugal, southwestern Spain, and northeastern Morocco. 4) Subspecies commutatus (Paol.) Thell. occurs in southeastern France, western Italy, and the Island of Corsica. 5) Subspecies fontanesii Thell. occurs in northern Tunisia. These results differ markedly from identifications suggested in some local floras. For example, Jury (2002), in the flora of northern Morocco, identified the gummifer morphotypes there as D. carota subsp. gummifer, while we identify them as subsp. halophilus. In addition, he included subsp. fontanesii and subsp. hispanicus sensu auct., non (Gouan) Thell. in synonymy of subsp. gummifer, while we consider these as separate valid subspecies. Other authors (e.g. Heywood 1968a, 1968b; Pujadas-Salvà 2002, 2003) recognize additional subspecies, usually based on morphological syndromes often associated to local narrow distributions.

Daucus carota subsp. capillifolius-With its long and very narrow leaf segments, non-radiate or slightly radiate flowers with yellowish petals, and mericarps comparatively longer than in other subspecies, subsp. capillifolius is the most distinctive one within the $D$. carota complex. It was classified at the species rank until a recent molecular analysis clearly revealed it to be imbedded within D. carota (Spooner et al. 2013). This subspecies is endemic to eastern Tunisia and northwestern Libya, mainly occurring in the sublittoral areas, no more than $200 \mathrm{~km}$ inland (Martínez-Flores 2016). McCollum (1975) showed that wild carrots (subsp. carota) cross readily with subsp. capillifolius, producing highly fertile hybrids with no sterility barriers. This fact might explain the position of putative intermediate accessions in Clade 1 (e.g. NGBTUN 155, 157, 158, and 160). Several plants grown from seeds of these accessions showed some morphological resemblance with subsp. capillifolius (e.g. yellowish petals and narrow leaf segments). The genetic structure of those samples indicates that they share alleles with both Tunisian subsp. carota and subsp. capillifolius (orange and brown theoretical populations, Fig. 1), which suggests DNA flow through introgressive hybridization.

Subspecies gummifer s. l.-Previous authors have recognized two morphological groups within the Daucus carota complex (e.g. Thellung 1926; Onno 1937; Nehou 1961; Small 1978; Bolòs and Vigo 1990). Small (1978) informally labelled these two groups subspecies aggregate carota (mainly cosmopolitan ruderal variants) and subspecies aggregate gingidium (found mostly on Mediterranean and adjacent Atlantic coasts). Previously, Thellung (1926) had used "Eucarota" and "Gummiferi" names for these same two groups. Other authors declined to recognize those groups (Heywood 1968b; Okeke 2015) or never indicated their relationships to each-other (Sáenz Laín 1981; Pujadas-Salvà 2002), while others maintained two subgroups (carota and gummifer) because of their practical utility (e.g. Reduron and Muckensturm 2007).

In agreement with Arbizu et al. (2016), our results demonstrate the "gummifer" subgroup to consist of five separate aggregates derived from subsp. carota / subsp. maximus accessions, with a clear geographic and genetic, but not clear morphological pattern. Several authors have indicated that taxa within Daucus carota subsp. gummifer s. 1. had wide overlapping distributions. For example, Okeke (2015) considered that subsp. halophilus and subsp. hispidus (Arcangeli) Heywood were sympatric along the southern Portugal coasts, subsp. gummifer and subsp. hispidus occurred together in western Morocco and northwestern Algeria, subsp. drepanensis (Arcang.) Heywood and subsp. gummifer in Occitania (southern France), and subsp. drepanensis, subsp. gummifer, and hispidus in Corsica and northeastern Libya. More recently, Reduron and Muckensturm (2007) considered: 1) D. carota subsp. commutatus to be widely distributed within the Mediterranean basin; 2) subsp. drepanensis could be present in many islands along the Mediterranean; 3) subsp. gummifer in the Atlantic coasts from England to Portugal and also (less frequently) in the Mediterranean; and 4) subsp. hispanicus widely distributed from western to central Mediterranean. Given those large ranges, it is not surprising to find putative sympatry of the gummifer morphotype taxa in some areas. For example, according to Reduron and Muckensturm (2007) distribution notes, subsp. commutatus, subsp. drepanensis, and subsp. hispanicus occur along the Corsica coasts. Nevertheless, our cladistic and genetic structure results support coastal morphotypes collected within a same area cluster together in narrower areas without sympatry (Fig. 3). We taxonomically interpret these data to recognize subspecies of the gummifer complex based also on geography, rather than morphology.

English Channel and Bay of Biscay Area (subsp. gummifer s. s.) - Along the western coast of Cornwall (UK), occurs the type locality of Daucus carota subsp. gummifer and nearby, from Belle-Île-en-Mer (France), the type locality of Daucus carota subsp. gadecaei (Rouy \& E.G.Camus) Heywood. These accessions, together with other specimens collected along seashores from southern UK and northwestern France form a highly supported subclade in Clade 3 (BS $=100 \%$, Fig. 5), that we 
recognize as Daucus carota subsp. gummifer. Specimens frequently ascribed to "gadecaei" represent a morphological extreme of variation, being plants with: 1) dwarf habit and procumbent branches, apparently subglabrous; 2) flat flowering umbels usually without central colored flowers; and 3) concave fruiting umbels.

Accessions along the southern part of the Bay of Biscay are usually characterised by dense indumentum and an overall resemblance with plants from England, and are included in subsp. gummifer by others (e.g. Sáenz Laín 1981; Pujadas-Salvà 2002; Martínez-Flores 2016). Our GBS results showed these specimens to be clustered on a $91 \%$ bootstrap clade but weakly related to the specimens described above. Their similarities in morphology, geography, and population structure lead us to classify all of them as subsp. gummifer. We found that some specimens had sparse indumentum (e.g. SA33794) and even subglabrous leaves similar to those in Daucus carota subsp. hispanicus. Merino (1913) and Pujadas-Salvà (2002) noted that morphological variability, and Reduron and Muckensturm (2007, Fig. 160) labelled a plant as Daucus carota subsp. gummifer var. gummifer collected in the Atlantic Pyrenees with very sparse indumentum. This morphological variability could be related to the population structure differences between northern and southern plants, with clear dominance of cyan membership in the northern and mainly cyan+blue+purple memberships in the southern accessions (Fig. 1, Clade 3 part 1 ). In our opinion, this points towards possible gummifer-hispanicus introgression, which could explain low support subclades within the general Clade 3 .

Southwestern Iberian Peninsula and Morocco (subsp. halophilus)_Coastal plants from southwestern Portugal traditionally have been considered an endemic taxon (e.g. Daucus carota subsp. halophilus, Pujadas-Salvà 2002). Accession E8728 was collected in the region of the type locality ("ex Ericeira usque ad Colares"; Brotero 1827). Notably, five accessions matching the gummifer morphotype and being identified as D. carota subsp. halophilus form a well-supported clade (BS $=88 \%$, Fig. 6). All those plants were collected in southwestern Portugal in the general area of the type locality of subsp. halophilus. We also place SA33797 from southwestern Spain and US31580 from adjacent Morocco in this subspecies. Our Structure analysis did not show differences between these coastal plants and nearby subsp. maximus and subsp. carota specimens from Morocco, Portugal, and Spain (Fig. 1). That fact might point towards large morphological plasticity not linked to genetic variability, but perhaps to environmental conditions.

Corsica and Ligurian Sea Area (subsp. commutatus)Several specimens with a recognizable "coastal morphotype" collected by the sea in Corsica, northern Italy, and southeastern France form a well-supported clade (BS = 88\%, Fig. 6). Bearing in mind geography and population structure resemblance (a characteristic purple+cyan+orange population pattern, Fig. 1), we placed accession F679 in this subspecies. Previous authors (e.g. Reduron and Muckensturm 2007; Okeke 2015) considered that several taxa belonging to the gummifer complex coexisted in Corsica and the Ligurian Sea area. However, our results place these plants as a single lineage. Within this clade, accession US7674 showed some morphological features usually ascribed to Daucus carota subsp. commutatus (Heywood 1968a, and, accordingly, Boccone 1674 and Pignatti 1982). Considering morphology and geography, we assign the name Daucus carota subsp. commutatus to coastal plants from Corsica and the Ligurian Sea area. The type locality of that subspecies is located in the Tyrrhenian Sea coasts and further studies should focus on the analysis of coastal plants from that area.

Western African Mediterranean, Tunisia (subsp.fontanesii)During our study three coastal morphotype specimens were collected along the Tunisian coast (NGBTUN 184, 246 and 247). Those specimens formed a strongly supported subclade (BS $=100 \%$ ) together with subsp. capillifolius and subsp. carota from Tunisia in Clade 1 (Fig. 4), and have a characteristic population structure pattern (orange+ purple+brown, Fig. 1). The coastal morphotypes from northwestern Africa have been frequently identified as subsp. fontanesii. Our lack of any additional coastal populations from Tunisia, and no specimens from Algeria, lead us at present to classify these Tunisian populations as subsp. fontanesii.

French Coastal Carrots-The taxonomic treatment of the coastal morphotype from France has varied greatly over time. Recently, Reduron and Muckensturm (2007) published a detailed review of Daucus carota from France in which they accept five coastal morphotypes: subsp. commutatus (Corsica), subsp. drepanensis (Corsica and distribution poorly known in continental Mediterranean France), subsp. gummifer var. fontanesii (Marseille, Corsica), subsp. gummifer var. gummifer (Atlantic coast, very rare presence, perhaps totally absent on the Mediterranean coast) and subsp. hispanicus (the entire Mediterranean coast and Corsica). In addition, they also accept the presence of Daucus carota subsp. gadecaei (mainly in Brittany, also cited in the French Basque Country). In our analysis, French coastal morphotypes are classified within three subspecies: specimens from the Atlantic coasts that we identify as subsp. gummifer (above), specimens from southwestern France (including the specimen F695 collected near Collioure, the type locality of Daucus carota subsp. hispanicus) that we classify as subsp. hispanicus, and subspecies commutatus, with two specimens examined from southern France and the others from the island of Corsica and Italy.

Former Genus Tornabenea-Both Tornabenea specimens included in our study, endemic to the Cape Verde Islands, nested with $D$. carota subsp. maximus and subsp. carota specimens collected in western Morocco and Spain. Morphological, chromosomal, and molecular relationships between some Tornabenea species and Daucus carota s. 1. have been reported previously (e.g. Spalik and Downie 2007; Weitzel et al. 2014; Banasiak et al. 2016; Martínez-Flores 2016; Martínez-Flores et al. 2019) and experimental crosses between Daucus carota subsp. sativus and Tornabenea tenuissima successfully demonstrated that there are no crossing barriers between those species (J.-P. Reduron in Banasiak et al. 2016). Accordingly, Banasiak et al. (2016) sunk Tornabenea annua, T. insularis, and T. tenuissima into Daucus, as D. annuus, D. insularis, and D. tenuissimus. Nevertheless, all evidence points out that at least some Tornabenea species should be included within the D. carota complex, constituting a remarkable case of allopatric speciation in the Cape Verde Islands with total or rarely almost total reduction of mericarp spines. These specimens still possess secondary ridges that usually interconnect the bases of those spines in Daucus carota (these expansions are described as "wings" in Tornabenea; e.g. Grosso et al. 2008) and large vittae with subtriangular section (typical feature in Daucus carota subspecies). Our GBS and population structure data support these specimens to have evolved from plants from 
northwestern Africa. This hypothesis awaits further study, but we consider suitable evidence to here establish the new combinations: Daucus carota subsp. annuus and Daucus carota subsp. tenuissimus (see below).

\section{Key to the Subspecies of Daucus carota in the Western Mediterranean and Surrounding Areas}

1. Pale yellow petals; very narrow sublinear "leaflet" lobes; rays 18-25; mericarp length 4.5-5.5 mm; Tunisian-Libyan area ... . . . . subsp. capillifolius

1. White to pinkish petals; wider, not sublinear "leaflet" lobes; usually more than 25 rays; mericarps length less than 4.5 mm . ............. 2

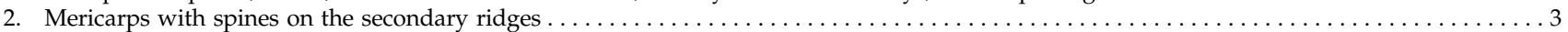

3. Taproot swollen and fleshy, colored in purple, red, orange, yellow, or white ("carrot"); cultivated plants .............. subsp. sativus

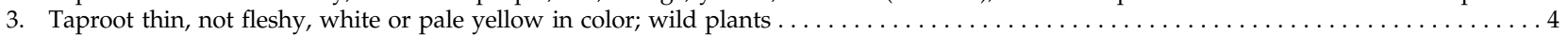

4. Fruiting umbel with markedly concave shape (mostly "closed nest-like" shape); sub-erect branches; subnitrophilous grasslands and similar

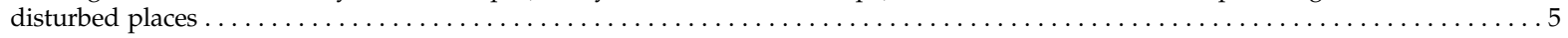

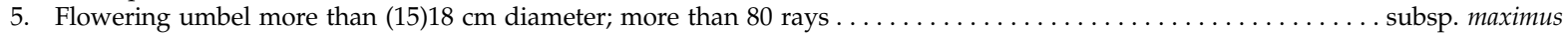

5. Flowering umbel less than $15 \mathrm{~cm}$ diameter; less than $70(80)$ rays $\ldots \ldots \ldots \ldots \ldots \ldots \ldots$. . . . . . . . . . . . . . . . . . . .

4. Fruiting umbel with convex to concave shape (sometimes "open nest-like," never "closed nest-like" shape); spreading-ascending branches;

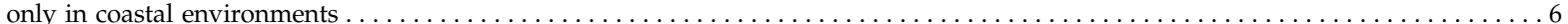
6. Balearic Sea and western Gulf of Lion areas; leaf rachis and "leaflets" often glabrous or almost glabrous ........ . subsp. hispanicus

6. Widespread but excluding the Balearic Sea and western Gulf of Lion areas; leaf rachis and "leaflets" usually hairy to almost covered by

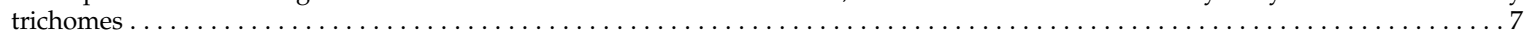

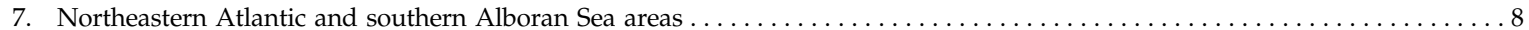

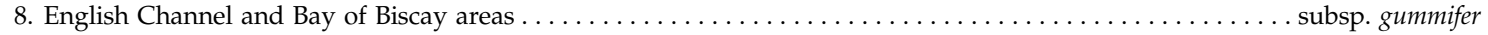

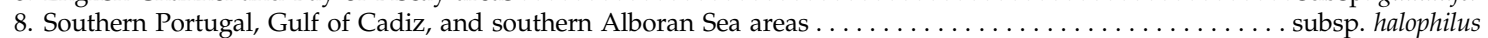

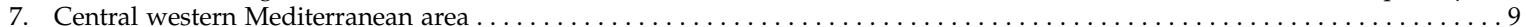

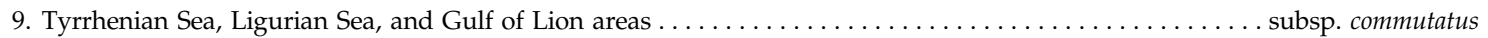

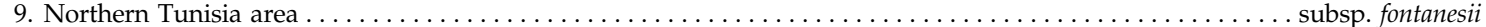

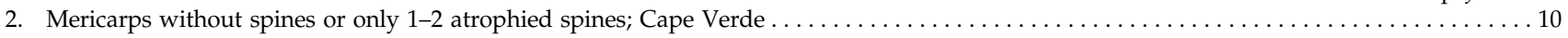
10. Mericarps with few simple trichomes; marginal secondary ridges slightly winged or even serrated (with 1-2 atrophied spines) .... subsp.

10. Mericarps glabrous; marginal secondary ridges neither winged or serrated $\ldots \ldots \ldots \ldots$. . . . . . . . . . . . . . . subsp. tenuissimus

Taxonomic Treatment of the Coastal ("GummifeR")

Populations of DaUcus carota in the Western Mediterranean and Surrounding Areas

\section{Accepted TAXA}

1. Daucus carota subsp. commutatus (Paol.) Thell. in Repert. Spec. Nov. Regni Veg. 22: 312. 1926

$\equiv$ Daucus carota var. commutatus Paol. in Fiori \& Paol., Fl. Italia 2: 186. 1900, basionym $\equiv$ Daucus gingidium subsp. commutatus (Paol.) O.Bolòs \& Vigo in Butl. Inst. Catalana Hist. Nat., Secc. Bot. 38(1): 84. 1974. Ind. loc: "Reg. med. in Tosc., Capraia, It. mer., Ischia, Sic., Eolie e Cors." LECTOTYPE (designated by Reduron and Muckensturm 2007: 1045): [icon] "Pastinaca tenuifolia sicula, hirsuta, crispa" in Boccone, Icon. Descr. Rar. Pl. Siciliae: 28, pl. 14 Fig. 2. 1674; EPITYPE (designated by Reduron and Muckensturm 2007: 1046): Italy, Sicily. "Pastinaca hirsuta, crispa, sicula", ["Inter Leocatam \& Agrigentum nascitur, in scopulo dicto San Nicolo”], Herb. Boccone pl. 59 (L)

= Daucus polygamus Gouan, Ill. Observ. Bot.: 9. 1773. LeCtoTYPE (designated by Reduron and Muckensturm 2007: 1045): [icon] "Pastinaca Oenanthes folio" in Boccone, Icon. Descr. Rar. Pl. Siciliae: 74, pl. 40 Fig. 3. 1674; ЕРІтүPE (designated here): [ITALY, SiCILY]. "Pastinaca Oenanthes folio ex Sicilia" ["Supra muros Leocatae Civitatis"], Herb. Boccone pl. $52(\mathrm{~L})]$

= Daucus siculus Tineo, Pl. Rar. Sicil. 1: 6. 1817. Ind. loc.: [ITALY, SICILY] "Hab. prope Drepanum". TYPE: not seen

= Daucus rupestris Guss., Fl. Sicul. Syn. 1: 335. 1842-43 $\equiv$ D. gingidium subsp. rupestris (Guss.) Onno in Beih. Bot. Centralbl., Abt. 2, 56 (Abt. B): 103. $1937 \equiv$ D. carota subsp. rupestris (Guss.) Heywood in Feddes Repert. 79: 68. 1968 D. australis Guss., Fl. Sic. Prodr. Suppl. 1: 74. 1832, nom. illeg. [non Poepp. ex DC., Prodr. 4: 214. 1830].- TyPE: not seen

= Daucus lopadusanus Tineo, Pl. Rar. Sicil, ed. 2, 3: 38. 1846. Ind. loc.: ITALy, SiciLy. "In aridis maritimis. Lampedusa, alla Cala Grande. Calcara." TYPE: not seen

= Daucus gingidium subsp. drepanensis Arcang., Comp. Fl. Ital.: 299. $1882 \equiv$ D. drepanensis (Arcang.) Tod. ex Lojac., Fl. Sicul. 1(2): 298. $1891 \equiv$ D. carota subsp. drepanensis (Arcang.) Heywood in Feddes Repert. 79: 68. $1968 \equiv$ D. communis subsp. gummifer Rouy \& E.G.Camus var. drepanensis (Arcang.) Rouy \& E.G.Camus, Fl. France 7: 239 . 1901, comb. inval. Ind. loc: "Loughi lapidosi maritime, S. Croce al Braccetto Citarda! ed anco Favignana Huet. secondo l'essemplare a cui sopra ho alluso. Maggio". LECTOTYPE (designated by Reduron 2013: 218): ITALY, SICILY, "Daucus drepanensis Tod. ined. Lojac." Santa Croce al Bracetto Citarda (PAL-22108)

$=$ Daucus carota subsp. corsoccidentalis Reduron in Bull. Soc. Bot. Centre-Ouest, nouv. sér., 48: 152 (2017). Ind. loc.: "Côte ouest de la Corse... Les populations se situent sur les littoraux rocailleux (calcaire, amiante, granite rose) en milieux héliophiles, xérothermiques." НоцотүPE (designated by Reduron et al. 2017: 153): FRANCE, Haute-Corse, Patrimonio, à la Punta di Saeta, éboulis calcaire sous falaise, exposition nord, $42^{\circ} 43.101^{\prime} \mathrm{N} 9^{\circ} 19.710^{\prime} \mathrm{E}, 6$ June 2012, J.-P. Reduron s.n. (G). [Fruits collected 16 August 2011].

= Daucus carota subsp. fontanesii var. meriensis Reduron in Bull. Soc. Bot. Centre-Ouest, nouv. sér., 48: 153 (2017). Ind. loc: "Nord-est du cap Corse, secteur de Meria [Corsica]. Falaises et talus ébouleux le plus souvent en situation ombragée, orientés à l'Est." LестоTYPE (designated by Reduron et al. 2017: 154): FRANCE, Haute-Corse, cap Corse, Marine de Meria, au sud de Macinaggio, talus abrupts, rebord de falaise, au bord de la route RD80, $44 \mathrm{~m}$ alt., $42^{\circ} 55^{\prime} 51^{\prime \prime} \mathrm{N} 9^{\circ} 27^{\prime} 55^{\prime \prime} \mathrm{E}, 17$ July 2014, J.-P. Reduron s.n. (G). 
- Daucus carota subsp. caporientalis Reduron in Bull. Soc. Bot. Centre-Ouest, nouv. sér., 48: 151 (2017), nom. inval. [Art. 40.7 of the ICN; Turland et al. 2018)]. Ind. loc: "Côte est du cap Corse [Corsica], rochers et coteaux rocailleux maritimes." НоLОтүре (designated by Reduron et al. 2017: 152): FRANCE, Haute-Corse, cap Corse, Marine de Pietracorbara à Ampuglia, rochers (micaschistes) en bordure de mer, $42^{\circ} 50.121^{\prime} \mathrm{N} 9^{\circ} 29.011^{\prime} \mathrm{E}, 13$ August 2011, J.-P. Reduron s.n. [No herbarium acronym cited]

- Daucus gummifer Lam., Encycl. 1: 634. 1785, nom. illeg. [non All., Syn. Meth. Stirp. Hort. Reg. Taur.: 30. 1773]

Estimated Distribution-Daucus carota subsp. commutatus is found at the Tyrrhenian Sea, Ligurian Sea, eastern Gulf of Lion, and western Ionian Sea coasts, including southern France, most Italian Peninsula, Corsica, Sardinia, Sicily, Malta, Lampedusa, Pantelleria, Linosa, and small islands nearby.

Notes-Plants from Trapani (western Sicily), described as D. gingidium subsp. drepanensis Arcang., occur in a small area close to populations of D. carota subsp. commutatus. Given that the distribution area and pattern of morphological variation in the pair "D. commutatus-D. drepanensis" parallels the case of the pair "D. hispanicus-D. carota subsp. majoricus A.Pujadas", we adopt a similar taxonomic solution, albeit molecular data are obviously needed to ascertain their evolutionary relationships. Posterior type indication for D. drepanensis by Okeke (2015) on material collected "In arenosis maritimes [sic] Trepani, Junio, Todaro 1037 (BM! iso, P! iso)" is therefore superfluous and not valid for eventual lectotype, since he cited two specimens referred to as isotypes. Regarding the name Daucus siculus Tineo, most probably it is also a synonym of $D$. drepanensis. Similarly, D. polygamus Gouan, a species described from Sicily, is also related to D. carota subsp. commutatus. Furthermore, plants occurring in the small islands of the central Mediterranean area (Lampedusa, Lampione, Malta) were named D. rupestris Guss. and D. lopadusanus Tineo, two taxa that appear to be related to $D$. carota subsp. commutatus. However, until new molecular data are available all three latter names are provisionally placed here.

Recently, Reduron et al. (2017) have described several new taxa (4 subspecies and one variety) from the coastal areas of Corsica which showed some genetic neutral microsatellite divergence apparently associated to slight morphological variation. Although some of the new taxa occurred in very close geographic sites, they suggested that those new subspecies and varieties were the result of ecological (sub)speciation processes. However, our analyses include Corsican samples gathered in sites very close to the type localities of such new taxa, all of which are nested in a well-supported clade corresponding to the gummifer complex from Corsica and the Ligurian Sea area, here accepted as D. carota subsp. commutatus. Some of them, such as D. carota subsp. otaportensis Reduron in Bull. Soc. Bot. Centre-Ouest, nouv. sér., 48: 154 (2017), from shady sites near Ota in the Gulf of Porto (Western coast of Corsica) or D. carota subsp. valeriae Reduron in Bull. Soc. Bot. Centre-Ouest, nouv. sér., 48: 156 (2017), nom. inval. (Art. 40.7 of the ICN; Turland et al. 2018), from near Albo in Cap Corse (northern coast of Corsica), are most probably intermediate forms (perhaps of hybridogenic origin) between $D$. carota subsp. carota and D. carota subsp. gummifer, and therefore are not explicitly included in synonymy of the latter subspecies.

According to our analyses, and contrarily to suggestions by Reduron et al. (2017), we consider that the genetic- morphologic study of those authors is a clear example to visualize the extreme morphological plasticity existing in the "coastal morphotypes," which can be highly variable in reduced geographic areas depending on the (micro)habitats they grow in. In our opinion, describing new taxa on the basis of such weak morphological microvariations in narrow geographic areas (in some cases due to putative hybridization processes) should be avoided, since it contributes to create a taxonomic inflation that much hinders understanding of higher scale speciation patterns of D. carota s. 1 .

2. Daucus carota subsp. Fontanesil Thell. in Repert. Spec. Nov. Regni Veg. 22: 314. 1926, nom. nov. $\equiv$ D. gingidium subsp. fontanesii (Thell.) Onno in Beih. Bot. Centralbl., Abt. 2, 56 (Abt. B): $103.1937 \equiv$ D. carota var. fontanesii (Thell.) Reduron, Ombellif. France 2: 1055. 2007. LестотуPE (designated here): "Daucus hispidus. Carote herisée". Habitat in fissuris rupium ad maris littora. Herbier de la Flore Atlantique, M. Desfontaines (P-00320310). Available at: https:/ / science.mnhn.fr/taxon/species/daucus / hispidus\#desf

三Daucus hispidus Desf., Fl. Atlant. 1: 243. 1798, nom illeg. [non Mill., Gard. Dict., ed. 8, Daucus num. 4. 1768], replac. syn. $\equiv$ D. gummifer subsp. hispidus Arcang., Comp. Fl. Ital. ed. 2: $616.1894 \equiv$ D. carota var. hispidus (Arcang.) Paol. in Fiori and Paol., Fl. Anal. Ital. 2(1): 187. 1900.

= Daucus jolensis Pomel, Nouv. Mat. Fl. Atl.: 146. 1874. Ind. loc.: Falaises et rochers maritimes d'Alger á Cherchell. LeCtotype (designated here): [Algeria, Tipaza], A Castiglione = Bou-Ismaël, Pomel (MPU-005034). IsOLECTOTYPES: MPU-005035, P-00466649.

Estimated Distribution-This subspecies is found along the coasts of Algeria and northern Tunisia.

Notes-Previous "holotype" indications for D. carota subsp. fontanesii by Reduron and Muckensturm (2007) and Okeke (2015) are not correctable to lectotype, neither are effective according to Art. 9.23 of the ICN. Therefore, the name is lectotypified here on the basis of the replaced name, D. hispidus Desf. (Art. 7.4 the ICN), since no evidence exists to consider that the material at $\mathrm{P}$ was the only one used by Desfontaines to describe his species. Plants from the coastal areas of eastern Algeria were described as D. jolensis Pomel. Although no material was included in our molecular analyses, plants from that territory are morphologically related to $D$. carota subsp. fontanesii, and therefore they are provisionally included here.

3. Daucus carota L. subsp. GUMMIFER (Syme) Hook.f., Student Fl. Brit. Isl. ed. 3: 185. 1884

$\equiv$ Daucus carota var. gummifer Syme in Sm., Engl. Bot. ed. 3[B] 4: 157.1865 , basionym $\equiv D$. gingidium subsp. atlanticum Rivas Mart. in Itinera Geobot. 15: 700. 2002, nom. nov. LECTOTYPE (designated by Reduron and Muckensturm 2007: 1068): [icon] "E.B. 2560. Daucus carota, var. gummifer. Sea carrot." in Smith, Engl. Bot. ed. 3, 4: pl. 616. 1865; EPITYPE (designated here): [UK, ENGLAND], S Devon: Hallsands (North), Start Bay, on semi-stabilized shingle, 24.vi.1953, W.B. Turrill 72/53 (K-000782423 [digital image!]).

= Daucus communis Rouy \& E.G.Camus [nom. illeg.] subsp. carota (L.) Rouy \& E.G.Camus f. gadecaei Rouy \& E.G.Camus, Fl. France 7: 237. $1901 \equiv$ D. carota subsp. 
gadecaei (Rouy \& E.G.Camus) Heywood in Feddes Repert. 79: 68. 1968. Lectotype (designated by Reduron and Muckensturm 2007: 1003): FRANCE. Morbihan, Belle-Île, pelouses rases des falaises au-dessus de la grotte de l'Apothicairerie, 19.viii.1901, leg. G. Rouy (LY).

= Daucus masclefii Corb., Nouv. Fl. Norm.: 264. 1893. TyPE: not seen.

Estimated Distribution-The subspecies is found on the English Channel and Bay of Biscay coasts, including southern UK, southern Ireland, western France, and northern Spain.

Notes-Regarding the type of D. carota var. gummifer, despite the illustration selected as lectotype shows an overall good quality, the hairy stems originally described were not depicted. To facilitate further work, an epitype is selected here from coastal plants collected in southern England. Some populations of NW France (Morbihan: Belle-île) display some morphological peculiarities that led some authors to recognise a different taxon, Daucus carota subsp. gadecaei (Rouy \& E.G.Camus) Heywood. Samples of this French taxon, however, are embedded among those of D. gummifer in our analyses and hence they are included here in synonymy. Although some databases (e.g. https://www.ipni.org/? $\mathrm{q}=$ Daucus\%20gadeeaei; http:/ / www.theplantlist.org / tpl1.1/record/kew-2757997) accept the specific combination “D. gadecaei Rouy \& E.G.Camus, Fl. France 7: 237. 1901," that taxon was indeed described as a form in 1901. To our knowledge, the combination at species rank was not validly published, and still is not stated. In a similar way, the intended new combination at subspecific rank established by Nehou (1961) as "Daucus carota subsp. gadecaei (Rouy \& E.G.Camus) Nehou" is not valid according to the Shenzhen Code (ICN; Turland et al. 2018). Okeke's (2015) previous type indication for that French taxon on a voucher collected in "Falaises de la Bretagne surtout sur les pelouses rases, Bell-Ile, Gadeceau (BM! syn)" is not valid for lectotype, since he explicitly cited it as a syntype. Lectotypification was effected by Reduron and Muckensturm (2007). Similarly, D. masclefii Corb. is morphologically close to D. carota subsp. gummifer and is also included here in synonymy.

4. Daucus carota subsp. Halophilus (Brot.) A.Pujadas in Anales Jard. Bot. Madrid 59: 374. 2002.

$\equiv$ Daucus halophilus Brot., Phytogr. Lusit. Select. 2: 198, Table 168 . 1827 , basionym $\equiv D$. hispanicus var. halophilus (Brot.) Samp. in Bol. Soc. Brot. ser. 2, 10: 239. 1935. LECтОтүРе (designated here): [icon] Daucus halophilus in Brotero, Phytogr. Lusit. Select. 2, Table 168 Fig. 7a3 \& 7b3. 1827.

= Daucus gingidium var. africanus Pau \& Font Quer, Iter Marocc. 1927: no. 462. 1928, in sched. LестотүPE (designated here): [MoROcCo]. Hab. in rupibus maritimus Marsa Quebira (Bocoya), 20 m. alt.; fl. 19 majii, fruct. 23.vii.1927, leg. Font Quer 462 (BCN-18038-1), the fruiting fragment on the sheet marked "L II/II". IsOLECTOTYPES: BC-24351, MA-89122, MPU-006280, MPU-006281.

Estimated Distribution-The subspecies is found in southern Portugal, Gulf of Cadiz, and Morocco, including southern Alboran Sea coasts.

Notes-Plants described from southern Alboran Sea (near Alhucemas) were named Daucus gingidium var. africanus Pau \& Font Quer. They are morphologically close to D. carota subsp. halophilus, and provisionally they are included here until new molecular data help to elucidate this point.

5. Daucus carota subsp. Hispanicus (Gouan) Thell. in Repert. Spec. Nov. Regni Veg. 22: 312. 1926.

= Daucus hispanicus Gouan, Ill. Observ. Bot. 9.: 1773, basionym $\equiv$ Daucus gingidium subsp. hispanicus (Gouan) O.Bolòs \& Vigo in Butll. Inst. Catalana Hist. Nat. 38: 84. 1974. Ind. Loc: "Ad mare juxta Perpinian E Colliauvre non infrequens (France)". NeOTYPE (designated as lectotype by Reduron and Muckensturm 2007): P-00321923 (http://mediaphoto.mnhn.fr/ media/1442443797137Ycexil6M9kv1hy2W); EPITYPE (designated here): [FRANCE]. Port Vendres, Cap Bear, 31TEH109071, $60 \mathrm{~m}$, en herbazales sobre laderas orientadas hacia el mar, 01.viii.2011, leg. F.Mart.Flores, C.Pena \& M.B.Crespo (ABH59127).

= Daucus carota subsp. majoricus A. Pujadas in Anales Jard. Bot. Madrid 59: 372. 2002 =D. gingidium subsp. majoricus (A.Pujadas) Mart.Flores, Juan, M.Á.Alonso, A.Pujadas \& M.B.Crespo, Proy. Invest. Parques Nac.: 146. 2007.- HoLOTYPE (designated by Pujadas-Salvà 2002): SPAIN. Baleares, Mallorca, Calvià, Santa Ponça, Punta Malgrats, 31SDD5373, 47 m, acantilado costero, 29.v.1986, leg. A.Pujadas (COA-24662).

Estimated Distribution-Daucus carota subsp. hispanicus is found at the Balearic Sea and western Gulf of Lion coasts, including northeastern Iberian Peninsula and nearby areas in southern France, central eastern Iberian Peninsula, all the Balearic Islands and Columbretes Islands.

Notes-The intended "lectotype" at Paris (P-00321923) selected by Reduron and Muckensturm (2007) was sent by Gouan to Jussieu, and lacks data about locality and collection date. It is an incomplete gathering including a single leaf and a fragment of a flowering stem, lacking fruits. No evidence indicates that voucher P-00321923 is part of the original material, and therefore we propose here to regard it as neotype of $D$. hispanicus. Furthermore, a suitable complete material that properly represents D. carota subsp. hispanicus s. s. is designated here as epitype, whose geographical origin is undoubtedly established and which will allow further eventual studies using modern techniques. Some populations from Mallorca (Balearic Islands) that were separated as Daucus carota subsp. majoricus A.Pujadas, are embedded among those of $D$. hispanicus and therefore both names are treated here in synonymy. Merino (1913) mentioned that some specimens he received from La Coruña (Galicia, NW Spain) seemed to be closer to the Mediterranean D. hispanicus than the typical Atlantic D. carota subsp. gummifer. We saw the same pattern in some specimens from NE Spain (coastal "hybrid" population). However, we have not seen any Galician specimen matching the morphology of the Mediterranean plants. Regarding the name Daucus nebrodensis Strobl in Oesterr. Bot. Z. 34: 223. 1884, it is actually a member of the $D$. carota aggregate occurring in mountain areas of Sicily, albeit has been often included in synonymy of $D$. hispanicus.

\section{INCERTAE SEDIS}

1. Daucus Russeus Heldr., Herb. Graec. Norm. ser. 3, no. 1631. $1901 \equiv$ D. carota subsp. russeus (Heldr.) Okeke, Systematic studies in Daucus L. (Umbelliferae): 278. 2015, comb. inval. $\equiv D$. gingidium subsp. polygamus var. russeus Onno in 
Beih. Bot. Centralbl., Abt. 2, 56 (Abt. B): 101. 1937. HoLOTYPE (indicated by Okeke 2015): [GREECE], "In scopulis Prasonisiu prope Delos, Cycladum", 11-12.vii.1901, leg. Tunetas $\mathcal{E}$ Russe 1631 (W!)

Estimated Distribution-This species is found at the eastern Ionian Sea and Aegean Sea coasts, including south Albania, Greek Peninsula and Islands, and western Turkey.

Notes-This name was proposed for plants collected from the Cyclades Islands, Greece (Okeke 2015). It has been synonymised to $D$. carota subsp. drepanensis (Arcang.) Heywood, and often applied to the eastern Mediterranean populations of coastal D. carota (Dimopoulos et al. 2013). Morphologically, members of that taxon show some resemblance to D. carota subsp. commutatus. However, no molecular information is available to ascertain its phylogenetic relationships, and hence it is not considered in synonymy. Further work is needed to elucidate the identity and the evolutionary connections of that eastern Mediterranean taxon.

\section{New Combinations Necessary to Accommodate Macaronesian Taxa in Daucus}

1. Daucus carota L. subsp. annuus (Bég.) Mart.Flores, D. M.Spooner \& M.B.Crespo comb. \& stat. nov.

$\equiv$ Tornabenea annua Bég. in Ann. Mus. Civico Storia Nat. Giacomo Doria, ser. 3, 8: 39. 1918, basionym $\equiv$ Melanoselinum annuum (Bég.) A.Chev. in Bull. Mus. Natl. Hist. Nat., sér. 2, 7: 144. 1935 三 Daucus annuus (Bég.) Wojew., Reduron, Banasiak \& Spalik in Taxon 65: 578. 2016. HoLOTYPE (designated by Béguinot 1918: 39): [REPUBLIC of CABO Verde] Is. di S. Thiago, dintorni di Orgãos Grandes, 300-600 m, iii-iv.1898 (fl. et init. fr.), Fea (GDOR).

Estimated Distribution-This subspecies is found in Cape Verde.

2. Daucus carota L. subsp. tenuissimus (A.Chev.) Mart.Flores, D.M.Spooner \& M.B.Crespo comb. \& stat. nov.

$\equiv$ Melanoselinum tenuissimum A.Chev. in Bull. Mus. Natl. Hist. Nat., sér. 2, 7: 143. 1935, basionym $\equiv$ Tornabenea tenuissima (A.Chev.) A.Hansen \& Sunding, Fl. Macaronesia ed. 2, 1: 92. $1979 \equiv$ Thapsia tenuissima (A.Chev.) M.Hiroe, Umbelliferae World: 1304. $1979 \equiv$ Daucus tenuissimus (A.Chev.) Spalik, Wojew., Banasiak \& Reduron in Taxon 65: 578. 2016. Holotype: [Republic of CABo Verde] Archipel des Iles du Cap Vert: Ile de Fogo: Pico Pires, 8.viii.1934, leg. A. Chevalier \#45188 (P; photo in Chevalier, 1935: 933).

Estimated Distribution-This subspecies is found at Cape Verde.

\section{ACKNOWLEDGMENTS}

We thank the curators and staff of the herbaria cited in the text for the loan of plant material and/or digital images of taxa of Daucus carota. Timothy Utteridge and Sally Dawson (Asia Team, Royal Botanic Gardens, Kew, UK) supplied British material for epitypification of D. carota subsp. gummifer. The genetic resources French network "Carrot and other Daucus" and Jean-Pierre Reduron (Via Apia, France) helped with accessions from France provided by IRHS, Agrocampus Ouest-INRA. This research was partly funded by the research grant UA2004-47056131 (University of Alicante) to FMF and by the USDA.
Author Contributions

FMS and MBC performed the taxonomic and nomenclatural analyses; HR performed the bioinformatic analyses; KR, EG, CA, and NM submitted germplasm from their respective genebanks; DMS conceived of this study and performed phylogenetic analyses. All authors contributed to writing the manuscript and approved the final version.

\section{Literature Cited}

Arbizu, C., H. Ruess, D. Senalik, P. Simon, and D. M. Spooner. 2014. Phylogenomics of the carrot genus (Daucus, Apiaceae). American Journal of Botany 101: 1666-1685.

Arbizu, C. I., S. L. Ellison, D. Senalik, P. W. Simon, and D. Spooner. 2016. Genotyping-by-sequencing provides the discriminating power to investigate the subspecies of Daucus carota (Apiaceae). BMC Evolutionary Biology 16: 234.

Banasiak, Ł., A. Wojewódzka, J. Baczyński, J. P. Reduron, M. Piwczyński, R. Kurzyna-Młynik, R. Gutaker, A. Czarnocka-Cieciura, S. KosmalaGrzechnik, and K. Spalik. 2016. Phylogeny of Apiaceae subtribe Daucinae and the taxonomic delineation of its genera. Taxon 65: 563-585.

Béguinot, A. 1918. Viaggio di Leonardo Fea nell'Africa occidentale. Contributo alla flora delle isole del Cabo Verde e notizie sulla sua affinita. Annali del Museo Civico di Storia Naturale Giacomo Doria ser. 3 8: 9-73.

Boccone, P. 1674. Icones et descriptiones rariorum plantarum Siciliae, Melitae, Galliae et Italiae. London: R. Scott Bibliopolam Londinensem.

Bolòs, O. de and J. Vigo. 1990. Flora dels Països Catalans, vol. 2. Barcelona: Barcino.

Bradbury, P. J., Z. Zhang, D. E. Kroon, T. M. Casstevens, Y. Ramdoss, and E. S. Buckler. 2007. TASSEL: Software for association mapping of complex traits in diverse samples. Bioinformatics 23: 2633-2635.

Brotero, F. de A. 1827. Phytographia Lusitaniae Selectior vol. 2. Lisbon: Ex Typographia Regia.

Chevalier, A. 1935. Les iles du Cap Vert. Géographie, biogéographie, agriculture. Flore de l'Archipel. Revue de Botanique Appliquée et d'Agriculture Coloniale 15: 733-109010.3406/jatba.1935.5553.

Danecek, P., A. Auton, G. Abecasis, C. A. Albers, E. Banks, M. A. DePristo, R. E. Handsaker, G. Lunter, G. Marth, S. T. Sherry, G. McVean, and R. Durbin. 1000 Genomes Project Analysis Group. 2011. The variant call format and VCFtools. Bioinformatics 27: 2156-2158.

Dimopoulos, P., T. Raus, E. Bergmeier, T. Constantinidis, G. Iatrou, S. Kokkini, A. Strid, and D. Tzanoudakis. 2013. Vascular Plants of Greece: An Annotated Checklist. Athens: Botanic Garden and Botanical Museum Berlin-Dahlem, Berlin \& Hellenic Botanical Society. Additional data available at: http:/ / portal.cybertaxonomy.org/ flora-greece/cdm_dataportal/taxon/dc473dbe-a8e8-4213-8807aa40068978d4.

Evanno, G., S. Regnaut, and J. Goudet. 2005. Detecting the number of clusters of individuals using the software STRUCTURE: A simulation study. Molecular Ecology 14: 2611-2620.

Francis, R. M. 2017. POPHELPER: An R package and web app to analyse and visualize population structure. Molecular Ecology Resources 17: 27-32.

Glaubitz, J. C., T. M. Casstevens, F. Lu, J. Harriman, R. J. Elshire, Q. Sun, and E. S. Buckler. 2014. TASSEL-GBS: A high capacity genotyping by sequencing analysis pipeline. PLoS One 9: e90346.

Grosso, A. C., L. Rodrigues, I. Gomes, E. S. Martins, and G. Teixeira. 2008. Preliminary data on microcharacters and chromosome number in Tornabenea species (Apiaceae) from Cape Verde Islands. Plant Biosystems 142: 87-93.

Hauser, T. P. and G. K. Bjørn. 2001. Hybrids between wild and cultivated carrots in Danish carrot fields. Genetic Resources and Crop Evolution 48: 499-506.

Heywood, V. H. 1968a. Daucus. Pp. 373-375 in Flora Europaea, vol. 2, eds. T. G. Tutin, V. H. Heywood, N. A. Burges, D. H. Valentine, S. M. Walters, and D. A. Webb. Cambridge: Cambridge University Press.

Heywood, V. H. 1968b. The Daucus carota-gingidium complex. Feddes Repertorium 79: 66-68.

Iorizzo, M., D. A. Senalik, S. L. Ellison, D. Grzebelus, P. F. Cavagnaro, C. Allender, J. Brunet, D. M. Spooner, A. Van Deynze, and P. W. Simon. 2013. Genetic structure and domestication of carrot (Daucus carota subsp. satious L.) (Apiaceae). American Journal of Botany 100: 930-938. 
Iorizzo, M., S. Ellison, D. Senalik, P. Zeng, P. Satapoomin, M. Bowman, M. Iovene, W. Sanseverino, P. Cavagnaro, M. Yildiz, A. MackoPodgórni, E. Moranska, E. Grzebelus, D. Grzebelus, H. Ashrafi, Z. Zheng, S. Cheng, D. Spooner, A. Van Deynze, and P. Simon. 2016. A high-quality carrot genome assembly reveals new insights into carotenoid accumulation and Asterid genome evolution. Nature Genetics 48: 657-666.

Jury, S. L. 2002. Daucus. Pp. 467-469 in Catalogue des Plantes Vasculaires du Nord de Maroc, Incluant des Clés d'Identification, eds. B. Valdés, M. Rejdali, A. Achhal El Kadmiri, S. L. Jury, and J. M. Montserrat. Madrid: Consejo Superior de Investigaciones Científicas (CSIC).

Lewis, P. O. 2001. A likelihood approach to estimating phylogeny from discrete morphological character data. Systematic Biology 50: 913-925.

Li, H. and R. Drubin. 2009. Fast and accurate short read alignment with Burrows-Wheeler transform. Bioinformatics 25: 1754-1760.

Martínez-Flores, F. 2016. Sistemática del Género Daucus L. (Apiaceae): Implicaciones Taxonómicas y Filogenéticas. Ph.D. thesis. Alicante: Universidad de Alicante, España.

Martínez-Flores, F., M. B. Crespo, E. Geoffriau, C. Allender, H. Ruess, C. I. Arbizu, P. Simon, and D. M. Spooner. 2019. Extended studies of interspecific relationships in Daucus (Apiaceae) using DNA sequences from ten nuclear orthologues. Botanical Journal of the Linnean Society 191: 164-187.

Martínez-Flores, F., M. B. Crespo, P. W. Simon, H. Ruess, K. Reitsma, E. Geoffriau, C. Allender, N. Mezghani, and D. M. Spooner. 2020. Data from: Subspecies variation of Daucus carota coastal ("gummifer") morphotypes (Apiaceae) using genotyping-by-sequencing. Dryad Digital Repositoryhttps://doi.org/10.5061/dryad.931zcrjg6.

McCollum, G. D. 1975. Interspecific hybrid Daucus carota $\times$ D. capillifolius. Botanical Gazette (Crawfordsville) 136: 201-206.

McCollum, G. D. 1977. Hybrids of Daucus gingidium with cultivated carrots (D. carota subsp. sativus) and D. capillifolius. Botanical Gazette (Crawfordsville) 138: 56-63.

Merino, B. 1913. Adiciones a la flora de Galicia (cont.). Brotéria, série Botânica 11: 182-201.

Mezghani, N., J. Ben Amor, D. M. Spooner, P. W. Simon, N. Mezghani, H. Boubaker, A. M. Namji, S. Rouz, C. Hannachi, M. Neffati, and N. Tarchoun. 2017. Multivariate analysis of morphological diversity among closely related Daucus species and subspecies in Tunisia. Genetic Resources and Crop Evolution 64: 2145-2159.

Mezghani, N., H. Ruess, N. Tarchoun, J. Ben Amor, P. W. Simon, and D. M. Spooner. 2018. Genotyping-by-sequencing reveals the origin of the Tunisian relatives of cultivated carrot (Daucus carota). Genetic Resources and Crop Evolution 65: 1359-1368.

Nehou, J. 1961. Recherches sur la taxonomie de genre Daucus (Ombellifères) en Bretagne. Bulletin de la Société Scientifique de Bretagne 36: 81-107.

Onno, M. 1937. Die wildformen von Daucus sect. Carota. Beihefte zum Botanischen Centralblatt 56(B): 83-136.

Okeke, S. E. 2015. Systematic Studies in Daucus L. (Umbelliferae). Ph.D. thesis. Reading: University of Reading. Presented in April 1978; published online at https: / / ethos.bl.uk/OrderDetails.do?uin=uk.bl.ethos.284332.

Pritchard, J. K., M. Stephens, and P. Donnelly. 2000. Inference of population structure using multilocus genotype data. Genetics 155: 945-959.

Pignatti, S. 1982. Flora d'Italia, vol. 2. Bologna: Edagricole.

Pujadas-Salvà, A. J. 2002. El complejo de Daucus carota L. (Apiaceae) en la flora Ibérica. Anales del Jardin Botanico de Madrid 59: 368-375.
Pujadas-Salvà, A. J. 2003. Daucus. Pp. 97-125 in Flora Iberica: Plantas vasculares de la península Ibérica e islas Baleares, vol. 10, eds. G. Nieto Feliner, S. L. Jury, and A. Herrero. Madrid: Real Jardín Botánico, CSIC.

Reduron, J. P. 2013. Additions et corrections suite à la parution de l'ouvrage "Ombellifères de France" 6. Bulletin de la Société Botanique du CentreOuest, nouvelle série, 44: 215-226.

Reduron, J. P. and B. Muckensturm. 2007. Daucus. Pp. 215-226 in Ombelliferes de France, vol. 2, ed. J. P. Reduron. Nercillac: Société Botanique du Centre-Ouest.

Reduron, J. P., M. Maghraoui, S. Huet, and E. Geoffriau. 2017. Avancées des connaissances sur le complexe spécifique Daucus carota L. en Corse et description de nouveaux taxons. Bulletin de la Société Botanique du Centre-Ouest, nouvelle série, 48: 147-158.

Rong, J., S. Janson, M. Umehara, M. Ono, and K. Vrieling. 2010. Historical and contemporary gene dispersal in wild carrot (Daucus carota ssp. carota) populations. Annals of Botany 106: 285-296.

Rubatzky, V. E., C. F. Quiros, and P. W. Simon. 1999. Carrots and related vegetable Umbelliferae. New York: CABI.

Sáenz Laín, C. 1981. Research on Daucus L. (Umbelliferae). Anales del Jardin Botanico de Madrid 37: 481-534.

Small, E. 1978. A numerical taxonomic analysis of the Daucus carota complex. Canadian Journal of Botany 56: 248-276.

Spalik, K. and S. R. Downie. 2007. Intercontinental disjunctions in Cryptotaenia (Apiaceae, Oenantheae): An appraisal using molecular data. Journal of Biogeography 34: 2039-2054.

Spooner, D. M. 2019. Daucus: Taxonomy, phylogeny, distribution. Pp. 9-26 in The Carrot Genome, eds. P. Simon, P., M. Iorizzo, D. Grzebelus, and R. Baransky. Cham: Springer, Nature.

Spooner, D. M., P. Rojas, M. Bonierbale, L. A. Mueller, M. Srivastav, D. Senalik, and P. W. Simon. 2013. Molecular phylogeny of Daucus (Apiaceae). Systematic Botany 38: 850-857.

Spooner, D. M., M. P. Widrlechner, K. R. Reitsma, D. E. Palmquist, S. Rouz, Z. Ghrabi-Gammar, M. Neffati, B. Bouzbida, H. Ouabbou, M. El Koudrim, and P. W. Simon. 2014. Reassessment of practical subspecies identifications of the USDA Daucus carota germplasm collection: Morphological data. Crop Science 54: 706-718.

Spooner, D. M., H. Ruess, M. Iorizzo, D. Senalik, and P. Simon. 2017. Entire plastid phylogeny of the carrot genus (Daucus, Apiaceae): Concordance with nuclear data and mitochondrial and nuclear DNA insertions to the plastid. American Journal of Botany 104: 296-312.

Stamatakis, A. 2014. RAxML Version 8: A tool for phylogenetic analysis and post-analysis of large phylogenies. Bioinformatics 30: 1312-1313.

Tange, O. 2011. GNU Parallel - The Command-Line Power Tool. The USENIX Magazine 36: 42-47.

Thellung, A. 1926. Daucus. Pp. 1501-1526 in Illustrierte Flora von Mitteleuropa, ed. G. Hegi. München: J. F. Lehmanns Verlag.

Turland, N. J., J. H. Wiersema, F. R. Barrie, W. Greuter, D. L. Hawksworth, P. S. Herendeen, S. Knapp, W.-H. Kusber, D.-Z. Li, K. Marhold, T. W. May, J. McNeill, A. M. Monro, J. Prado, M. J. Price, and G. F. Smith. 2018. International Code of Nomenclature for algae, fungi, and plants (Shenzhen Code) adopted by the Nineteenth International Botanical Congress Shenzhen, China, July 2017. Regnum Vegetabile 159. Glashütten: Koeltz Botanical Books.

Weitzel, C., N. Rønsted, K. Spalik, and H. T. Simonsen. 2014. Resurrecting deadly carrots: Towards a revision of Thapsia (Apiaceae) based on phylogenetic analysis on nrITS sequences and chemical profiles. Botanical Journal of the Linnean Society 174: 620-636. 